\title{
Fruits and Vegetables as Dietary Sources of Antimutagens
}

\author{
Satyendra Gautam ${ }^{1,2^{*}}$, Sudhanshu Saxena ${ }^{1}$ and Sanjeev Kumar ${ }^{1}$ \\ ${ }^{1}$ Food Technology Division, Bhabha Atomic Research Centre, Mumbai-400085, India \\ ${ }^{2}$ Homi Bhabha National Institute, Anushaktinagar, Mumbai-400094, India
}

Correspondence to:

Satyendra Gautam

Food Science and Safety Section

Food Technology Division, Bhabha Atomic

Research Centre, Mumbai-400085, India

Tel: 91-22-25595379

Fax: 25505151

E-mail: sgautam@barc.gov.in

Received: March 07, 2016

Accepted: June 17, 2016

Published: June 21, 2016

Citation: Gautam S, Saxena S, Kumar S. 2016. Fruits and Vegetables as Dietary Sources of Antimutagens. J Food Chem Nanotechnol 2(3): 97114.

Copyright: @ 2016 Gautam et al. This is an Open Access article distributed under the terms of the Creative Commons Attribution 4.0 International License (CC-BY) (http://creativecommons. org/licenses/by/4.0/) which permits commercial use, including reproduction, adaptation, and distribution of the article provided the original author and source are credited.

Published by United Scientific Group

\begin{abstract}
Mutation is the process leading to heritable changes in the genetic material of an organism and caused mainly by the external factors, including chemical and physical agents, or can also occur spontaneously due to errors in DNA replication, repair, and recombination. Agents contributing to the mutagenic burden in the environment could be from industrial sources, wide spectrum applications of biocides in the agriculture, and other contaminants. As many of these mutagenic chemicals can induce severe disorders in humans including cancer and a large spectrum of inherited diseases, it is important to detect such mutagenic agents precisely and rapidly, and also look for an approach to combat them. Natural occurring dietary antimutagens primarily from health protective foods such as fruits and vegetables could provide a mechanism to counteract the deleterious effect of these mutagens. The World Health Organization (WHO) indicates that one-third of all cancer deaths are preventable and that diet is closely linked to cancer prevention. These health protective phytochemicals particularly antimutagenic ones could provide an effective solution to these concerns. The current review deals with understanding of the mutagenic events, methods of its analysis and a brief compilation of the existing scientific findings related to the dietary sources having potential to counteract the effects of the mutagenic exposures from different sources. The review would provide an opportunity to look into the science, think about the possible future perspectives and mechanism to translate the outcome of the scientific research for benefits of the mankind.
\end{abstract}

\section{Keywords}

Mutagens, Vegetables, Fruits, Antimutagenicity

\section{Introduction}

Mutation is the process leading to heritable changes in the genetic material of an organism. The mutagenesis is primarily caused by the chemical and physical agents called as mutagens. Additionally, mutations can also occur spontaneously due to errors in DNA replication, repair, and recombination. Some mutagenic events can affect only one or a few nucleotides within a gene and hence called as point mutations. These base pair substitutions i.e. the replacement of one base pair with another primarily could be a deletion (the loss of one or more base pairs) or an insertion (the addition of extra base pairs into the DNA sequence). Mutagenic changes that occur in germ line cells can be passed to future generations. Agents contributing to the mutagenic burden in the environment could be from industrial sources, biocides (e.g. insecticides, herbicides, and pesticides) used in the agriculture, and the natural biotic (e.g. toxigenic microbes including 
fungi) or abiotic (e.g. radiation) sources. Occasionally dietary agents can also add to the mutagenic burden. For example when protein-rich foods such as meat and fish are cooked, a family of heterocyclic and polycyclic aromatic amines could be formed. The amount of these amines depends on cooking conditions (boiling, barbecuing, frying, and grilling) and or on meat type (beef, chicken, mutton, or pork). These heterocyclic aromatic amines have been reported to induce DNA damage in mammalian cells [1] and are potent multi organ carcinogens in rodents [2]. Besides, high nitrate levels in processed foods may also be a risk factor, possibly through their ability to form $\mathrm{N}$-nitroso compounds in vivo, as these chemicals induce tumors in various organs including liver, lung, kidney, bladder, pancreas and tongue [3]. Epigenetic changes in DNA methylation patterns at $\mathrm{CpG}$ sites termed as epimutations has emerged as a mechanism involved in tumor progression [4].

As many of these mutagenic chemicals can induce severe disorders in humans including cancer and different inherited diseases, it is important to detect such mutagenic agents precisely and rapidly, and develop strategy for nullifying their action [5-8]. Dietary antimutagenic phytochemicals from health protective foods such as fruits and vegetables could provide means to counteract the deleterious effect of these mutagens. Diet is closely linked to cancer prevention and as per the estimate of the World Health Organization (WHO) around one-third of all cancer deaths are preventable. Numerous epidemiological findings have indicated the potential of dietary phytochemicals as an effective intervention in combating carcinogenesis [9]. Hence, severe adverse events are conceivably less likely to arise in therapeutic settings using natural sources compared to synthetic compounds.

\section{Mutagens and Their Types}

Mutagens are either direct or indirect acting. The directacting mutagens affect genetic material directly leading to structural change (e.g. sodium azide- $\mathrm{NaN}_{3}$ ), whereas indirect acting mutagens works in an indirect manner through the metabolic activation leading to the formation of metabolites or different chemicals which directly acts upon DNA. During this process, the transformation of promutagen into the mutagen takes place primarily by the action of phase I metabolic enzymes, such as the cytochrome P450. The mutagen activation involves $\mathrm{N}$-oxidation by cytochrome P4501A2 followed by the activation by $\mathrm{N}$-acetyltransferase [10]. Some common examples of direct and indirect acting mutagens with their possible mechanism of action have been documented in Tables 1 and 2. Different mutagens work through different mechanism of action as detailed below.

\section{Alkylating agents}

These agents react with DNA bases directly and transfer an alkyl group to form its mono-adducts. N-methyl-N'-nitro-Nnitrosoguanidine (MNNG) and ethyl methanesulfonate (EMS) are the well-known alkylating agents. Alkylation of bases results in their mispairing eventually affecting the primary structure of the translated protein when these changes take place in exon (i.e. transcribing) regions of the DNA [11]. The most frequent location of alkylation in DNA by EMS is at guanine, leading to the formation of $\mathrm{O}^{6}$-alkylguanine [12]. During DNA replication thymine is placed instead of cytosine opposite $\mathrm{O}^{6}$-alkylguanine by the DNA polymerase. Thus during subsequent row of replication, the original $\mathrm{G}$ :C pair can become A:T pair. The process is called transition mutation. Similarly, MNNG acts by adding alkyl group to $\mathrm{O}^{6}$ of guanine or $\mathrm{O}^{4}$ of thymine leading to $\mathrm{G}: \mathrm{C}$ to $\mathrm{A}: \mathrm{T}$ transition $[13,14]$.

Table 1: Some common direct acting chemical mutagens and their mechanisms of action.

\begin{tabular}{|c|c|c|}
\hline Mutagen & Mechanism of action & Ref. no. \\
\hline Acridine & $\begin{array}{l}\text { Binds DNA tightly but } \\
\text { reversibly through intercalation } \\
\text { (at low concentrations) }\end{array}$ & {$[154]$} \\
\hline 9-aminoacridine & $\begin{array}{l}\text { Induces frameshift mutations } \\
\text { where a single base, especially } \\
\text { guanine, is repeated }\end{array}$ & {$[154]$} \\
\hline Doxorubicin & $\begin{array}{l}\text { Induces G:C-T:A transversions, } \\
\text { and also undergoes electron } \\
\text { reduction leading to the } \\
\text { generation of free radical species }\end{array}$ & {$[155,156]$} \\
\hline $\begin{array}{l}\text { Ethyl } \\
\text { methanesulfonate }\end{array}$ & $\begin{array}{l}\text { An alkylating agent. At low } \\
\text { concentrations alters a base in } \\
\text { DNA, and may induce DNA } \\
\text { strand breaks and lesions as a } \\
\text { consequence of depurination }\end{array}$ & {$[157,158]$} \\
\hline $\begin{array}{l}\text { Methyl } \\
\text { methanesulfonate }\end{array}$ & $\begin{array}{l}\text { An alkylating agent. Modifies } \\
\text { guanine and adenine to cause } \\
\text { base mispairing and replication } \\
\text { blocks, respectively }\end{array}$ & {$[159]$} \\
\hline $\begin{array}{l}\mathrm{N} \text {-methyl- } \\
\mathrm{N}^{\prime} \text {-nitro-N- } \\
\text { nitrosoguanidine }\end{array}$ & $\begin{array}{l}\text { Leads to the alkylation of purines } \\
\text { and pyrimidines. Leads to } \\
\text { formation of } \mathrm{O}^{6} \text {-methylguanine }\end{array}$ & $\begin{array}{c}{[14,155,} \\
160]\end{array}$ \\
\hline $\begin{array}{l}\text { 4-nitro-o- } \\
\text { phenylenediamine }\end{array}$ & Induces frameshift mutations & {$[155]$} \\
\hline 1-nitropyrene & $\begin{array}{l}\text { Forms DNA adduct } \\
\text { N-(deoxyguanosine-8-yl)-1- } \\
\text { aminopyrene }\end{array}$ & {$[161]$} \\
\hline $\begin{array}{l}\text { 4-nitroquinoline- } \\
\mathrm{N} \text {-oxide }\end{array}$ & $\begin{array}{l}\text { A base substitution agent, } \\
\text { principally acting at G residues. } \\
\text { Induce mainly GC to AT } \\
\text { transitions }\end{array}$ & {$[162]$} \\
\hline $\begin{array}{l}\text { Sodium azide } \\
\left(\mathrm{NaN}_{3}\right)\end{array}$ & $\begin{array}{l}\text { Mutagenicity is mediated } \\
\text { through the production of } \\
\text { L-azidoadenine that interacts } \\
\text { with DNA and causes point } \\
\text { mutations in the genome, } \\
\text { Induces } \mathrm{G}: \mathrm{C} \rightarrow \mathrm{A}: \mathrm{T} \text { transitions }\end{array}$ & {$[14,155]$} \\
\hline
\end{tabular}

Note: Table modified and drawn from ref. 25.

\section{Base analogs}

Such chemicals can substitute for a normal base in nucleic acid. It can be either purine or pyrimidine analogue. These molecules have structure similar to normal DNA bases and hence, can substitute a base in genetic material, leading to transitions and tautomerization. The common examples are 5-bromouracil (5-BrU), and 2-amino-purine (2-AP). Primarily, 5-bromouracil (5-BrU) is an analogue of thymine. $5-\mathrm{BrU}$ exists in tautomeric forms. The keto form pairs with adenine whereas enol form pairs with guanine. 
These tautomeric forms frequently interchange so base pairing properties can become altered at any time. The base pair will change from an $\mathrm{A}: \mathrm{T}$ to a $\mathrm{G}: \mathrm{C}$ or from a $\mathrm{G}: \mathrm{C}$ to an $\mathrm{A}: \mathrm{T}$ pair after a number of replication cycles. 2-AP is an analogue of guanine or adenine and most commonly pairs with thymine but can also pair with cytosine [7].

Table 2: Some common indirect acting chemical mutagens and their mechanisms of action.

\begin{tabular}{|l|l|c|}
\hline Mutagen & Mechanism of action & Ref. no. \\
\hline $\begin{array}{l}\text { N-acetyl-2- } \\
\text { aminofluorene }\end{array}$ & $\begin{array}{l}\text { Reacts with guanines at the C8 } \\
\text { position in DNA to form a structure } \\
\text { that interferes with DNA replication }\end{array}$ & {$[163]$} \\
\hline 2-aminoanthracene & $\begin{array}{l}\text { Its electrophilic reactive metabolites } \\
\text { form DNA adducts }\end{array}$ & [164,165] \\
\hline 2-aminofluorene & $\begin{array}{l}\text { Gets converted to reactive carcinogenic } \\
\text { ester 2-acetylaminofluorene-N-sulfate, } \\
\text { which can attack guanine residues in } \\
\text { nucleic acids }\end{array}$ & {$[166]$} \\
\hline $\begin{array}{l}\text { Aflatoxin B1 } \\
(\text { AFB1) }\end{array}$ & $\begin{array}{l}\text { Stimulates the release of free radicals, } \\
\text { which cause chromosomal aberrations }\end{array}$ & {$[167]$} \\
\hline Benzo( $\alpha)$ pyrene & $\begin{array}{l}\text { An active mutagen is benzo[a] } \\
\text { pyrene-7, 8-diol-9, 10-epoxide } \\
\text { (BPDE). Major adducts of BP-DNA } \\
\text { are BPDE-deoxyguanosine (dG) and } \\
\text { 9-OH-BP-dG-derived adducts }\end{array}$ & {$[168]$} \\
\hline Cyclophosphamide & $\begin{array}{l}\text { Alkylate DNA and also leads to free } \\
\text { radical production }\end{array}$ & {$[48]$} \\
\hline
\end{tabular}

Note: Table modified and drawn from ref 25.

\section{Intercalating agents}

They mimic base pairs and are able to insert between DNA bases at the core of the DNA double helix. This results in single-nucleotide pair insertions and deletions leading to frame-shift mutations. Its common example include acridines such as proflavine and quinacrine; exo 8, 9 epoxide of aflatoxin B1; and ethidium bromide. 9-Aminoacridine (9-AA) binds to DNA non-covalently by intercalation and causes frame shift mutations [15].

\section{Antimutagens and Mechanism of Action}

Looking for the compounds with antimutagenic properties is currently an intriguing area of research. Such compounds are under consideration to be used in combination with chemotherapeutic drugs having mutagenic potential to reduce its negative effect. The concept is quite relevant for the drugs being applied in cancer therapy because most of these drugs are DNA damaging agents and hence potential mutagens too. Many of these drugs may induce mutation in bystander cells and thus can cause secondary oncogenesis later in the patients that underwent chemical and/or radiation therapies even after the cure of the primary cancer. Such events are quite noticeable in case of cancers where therapeutic success rate is comparatively high. Therefore, searching for compounds with antimutagenic potency and understanding its mode of action bears immense significance [16]. Some antimutagens function at extracellular level by inactivating mutagenic agents and thus prevent their reach to the target (i.e. DNA), whereas others act within the cell and participate in mutation suppression after DNA damage by influencing genome repair and replication [17-19]. The first type of antimutagens are termed as 'desmutagens', whereas later as a 'bioantimutagens'. In recent studies some of the natural dietary constituents have been found to work through suppression of error prone pathway and also through up-regulation of genes that have been found to prevent mistranslation error [20, 21]. Occasionally certain compounds may exhibit dual nature and display both antimutagenic and mutagenic effects as reported in case of $\beta$-carotene, which possesses the ability to both scavenge and produce free radicals [22]. Such compounds have been termed as "Janus mutagens", after the Roman god who had one head with two faces looking in opposite directions [23-25]. Several antitumor compounds also displayed antimutagenicity [26-28].

\section{Mechanisms of antimutagenic action}

\section{Direct physical interaction with mutagens}

This is actually based upon direct chemical interaction between an antimutagenic compound and a mutagen before it induces DNA damage. Sulfhydryl compounds, such as cysteine was found to interact with 3-chloro-4(dichloromethyl)-5-hydroxy-2 $(5 \mathrm{H})$-furanone (MX) and thus reduce its mutagenicity [29]. Phenolics too were reported to work through direct interaction $[19,30]$. They work through two mechanisms. An extracellular mechanism involves interference with the cytochrome P450-mediated metabolism of these mutagens and the interaction with active mutagenic metabolites [31]. Their intracellular action is related to the protection of DNA from electrophilic mutagens [31]. Antimutagenic properties of gallic acid when assayed by the Ames test, were found to be possibly due to its nucleophilic property leading to the scavenging of the electrophilic mutagens [32]. Besides the gallic acid can also bind or insert into the outer membrane transporters and lead to the blockage of a mutagen that was transferred into the cytosol.

\section{Blockage of mutagen binding to the target}

Certain antimutagens work by blocking the mutagen binding to DNA [33]. Two synthesized $\beta$-amino ketones have demonstrated their antimutagenic action against MNNG and 9-aminoacridine (9-AA) induced mutagenicity through this mechanism [33].

\section{Inhibition of promutagen bioactivation}

Some compounds have been reported to inhibit promutagen bioactivation as reported in case of synthesized nitrogen- and oxygen-containing heterocyclic compounds against $\mathrm{NaN}_{3}$ and MNNG induced mutagenicity in the Ames and Escherichia coli WP2 bacterial reverse mutation assays. They were reported to work through possible inhibition of L-azidoalanine and $\mathrm{O}^{6}$-methylguanine formation [34]. Similarly, Terminalia arjuna constituents were reported to suppress the mutagenic effect of the aromatic amine, i.e., 2aminofluorene (2-AF) by inhibiting its metabolic activation [35].

\section{Antimutagenicity through antioxidant mechanism}

Not always but in some cases mutagens act through 
the generation of reactive oxygen species (ROS). In these cases scavenging of the ROS seems to be the principal mechanism of antimutagenicity [36-38]. Lipoic acid (LA) is one such example which has shown potent antioxidant activity and also antimutagenicity against mitomycin-C induced mutations in human peripheral lymphocytes [3942]. Similarly, antimutagenic activity of the lichen extracts was found to be closely related to its antioxidant capacity [43-45]. Acacia salicina extracts too provided protection against DNA strand break induced by the hydroxyl radical, and also significantly decreased mutagenicity induced by 4-nitro-O-phenylenediamine [46]. In another study, synthetic antimutagens like organoselenium compounds protected against genotoxicity and oxidative stress induced by an indirect-acting mutagen cyclophosphamide (CP) possibly through multiple antioxidant mechanisms such as activation of superoxide dismutase (SOD) and catalase, restoration of the level of glutathione (GSH), and the removal of ROS [47]. $\mathrm{CP}$ is known to work through DNA- alkylating mechanism and also free radicals production [48]. Bichalcophenes too significantly decreased the mutagenicity induced by sodium azide $\left(\mathrm{NaN}_{3}\right)$ and Benzo( $\alpha$ )pyrene (BP) [49].

However, not in all the cases, the antimutagenicity and antioxidant capacity are correlated. In the case of many foods such as different cultivars of apple, honey, and various vegetables, the extracted or purified bio-actives did not show good correlation between the antioxidant and antimutagenic activities [20, 21, 50-55]. However, some antimutagenic compounds which are not potent antioxidants on their own but can be converted into molecules that display good antioxidant activity as reported in case of several amino acid conjugates of curcumin demonstrated very high antimutagenic activity against $\mathrm{NaN}_{3}$ and methyl methanesulfonate (MMS) in Ames test [56].

\section{Methodology to Assess Mutagenicity and Antimutagenicity}

The screening strategy for mutagenic events and antimutagenicity potential of test compound relies upon the standard in vitro and in vivo assays. Depending upon the mode of screen a wide variety of genetic damage such as gene mutation, chromosomal damage, and aneuploidy can be detected by some of these assays. Both in vitro and in vivo testing methods are basically used to identify the same endpoints [57]. In antimutagenicity assay, cells are treated with the potential antimutagenic test compound along with a known standard mutagen prior to analysis.

These assessments protocol has been divided into three phases. Phase 1 is based upon in vitro tests involving cultured bacterial and mammalian cells. Phase 2 involves in vivo assessment of activity in somatic cells. Phase 3 assays screen for germ cell mutagens $[58,59]$. Phase 1 assays are primarily used for the identification of gene mutations and chromosome alterations. In the early mutagenicity assessment, two or three different tests in bacteria and mammalian cells should be used. The bacterial mutation assays such as Salmonella typhimurium and $E$. coli WP2 reverse mutation tests are useful tool for point mutations identification. Mammalian mutation assays are useful especially in case of bactericidal compounds and agents acting preferentially on the replication system in mammals. Common Phase 1 in vitro mammalian tests include: the mouse lymphoma thymidine kinase (TK) gene mutation assay, which detect compounds that induce forward gene mutations in the tk gene of the L5178Y mouse lymphoma cell line, and the hypoxanthine guanine phosphorybosyl transferase ( $h p r t$ ) gene mutation assay, which identifies agents that cause gene mutations in the hprt gene of a suitable cell line, such as Chinese hamster cells [57-60]. These phase 1 assays have many advantages, including their simplicity, relatively low cost, sensitivity, and flexibility to different experimental settings [61]. In addition, such tests may also provide some clues about the possible mechanisms of mutagenicity. Phase 2 in vivo assays can be used in the verification of the positive results obtained Phase 1 testing. The common procedure is screening for cytogenetic damage by metaphase analysis assay or the micronucleus test. Other in vivo assays include transgenic animal assays for point mutations, which can be used for the simultaneous detection of mutagenic effects in various tissues; DNA strand breakage assays, such as comet assay (also called as the single-cell gel electrophoresis assay), which detect single- and double-strand breaks, repair induced breaks and alkali-labile lesions; and the liver unscheduled DNA synthesis (UDS) test, which is useful for the measurement of the repair of DNA lesions [57, 58]. Compounds that give positive results for mutagenic potential in somatic cells in vivo should be further tested with germ cells. Phase 3 comprises of two classes of assays. Class 1 includes assays in germ cells per se, such as gene mutation tests in transgenic animals; paternal germinal mutation in the expanded simple tandem repeat (ESTR) test; and chromosomal aberration tests, whereas class 2 assays deal with the identification of alterations in offspring of mutagen exposed animals by testing for gene mutations in the ESTR assay; mouse visible specific locus test for detecting and quantifying the induction of heritable point mutations in mammals; the biochemical specific locus test for detection of mutations originating in the germ line of a mammalian species; and the dominant lethal test for chromosome or gene mutations $[58,62]$.

\section{Some of these assays are discussed below.}

\section{The Ames test (S. typhimurium/microsome assay)}

The Ames test uses several genetically engineered strains of the bacterium $S$. typhimurium that carry mutations in genes involved in histidine biosynthesis. These strains are auxotrophic mutants, i.e. they require histidine for growth, but cannot produce it. The method tests the capability of the test compound in creating mutations that result in a reversion to a "prototrophic" state, so that the cells can grow on a histidinefree medium. It is one of the most widely used short-term mutagenicity/antimutagenicity test $[63,64]$. The test detect mutagenic agents acting with different mutation mechanisms, such as base-pair substitution and frame shift mutations using specific strains. Similarly, antimutagenic activity of compounds against induced mutations can also be evaluated [64]. Rat liver extract is added to activate the indirect acting mutagens such as benzo $[\alpha]$ pyrene. The Ames test was initially developed using 
agar plates (the plate incorporation technique), as described above. Later a popular alternative method called 'fluctuation method'was also developed. In this method by including a $\mathrm{pH}$ indicator, the frequency of mutation is counted in microplates as the number of wells which have changed color due to drop in $\mathrm{pH}$ due to metabolic processes of reproducing bacteria. The fluctuation method is comparable to the traditional pour plate method in terms of sensitivity and accuracy [65].The test serves as a quick and convenient assay to estimate the carcinogenic potential of a compound because standard carcinogen assays on mice and rats are time-consuming and expensive. However, false-positives and false-negatives are known. Early studies showed that $50-70 \%$ of known carcinogens may be identified via this test [66-68]. Also the dose response curve using varying concentrations of chemical is almost always linear, indicating. that there is no threshold concentration for mutagenesis [66, 67]. However, some proposed that organisms can tolerate low level of mutagens due to protective mechanisms such as DNA repair, and threshold may exist for certain chemical mutagens $[63,64]$.

\section{E. coli WP2 tryptophan reverse mutation assay}

It detects $\operatorname{trp}-$ to $\operatorname{trp} \mathrm{C}$ reversion at a site blocking a step in the biosynthesis of tryptophan prior to the formation of anthranilic acid. E. coli strain WP2 is a radiation resistant derivative of $E$. coli $\mathrm{B} / \mathrm{r}$ which was the strain used by Luria and Delbrück [69]. This assay is primarily useful in the detection of $\mathrm{A} / \mathrm{T}$ base pair damage [70]. The target site for a site specific back mutation is an ochre (UAA) nonsense mutation [71, 72]. The assay is unable to detect frame shift mutations [73]. Like Ames test this assay has also comparatively higher rate of spontaneous tryptophan revertant colonies per plate [70].

\section{SOS chromotest}

In this assay E. coli PQ37 mutant strain allows the assessment of DNA changes induced by various mutagens through a colorimetric assay by means of fusion of a SOS regulon gene (responsive to the genotoxic compounds) with a reporter gene $\beta$-galactosidase (lac $Z$ ) [74]. Two genes play a key role in the SOS response: lexA encodes a repressor, and $\operatorname{rec} A$ encodes a protein able to cleave the LexA repressor (by autocatalytic mechanism) upon activation by an SOS inducing signal. By including a lactose analog which yields a colored compound upon degradation, an easily observable or quantifiable change in colour is obtained. Since the chemical tested may inhibit protein synthesis at higher concentrations, which would lead to an underestimation of $\beta$-galactosidase induction, alkaline phosphatase is assayed simultaneously in order to scale the data to survivability of the cells. The test is performed over a few hours in columns of a 96-well microplate. The test is comparable in accuracy and sensitivity to other established methods such as the Ames test.

\section{$r p o B$-rifampicin resistance assay}

The Rif $^{S} \rightarrow$ Rif $^{R}$ (rifampicin sensitive to resistant) test is based on acquisition of rifampicin resistance by $E$. coli MG1655 cells upon mutagen exposure (Figure 1). The rpoB gene encodes the $\beta$-subunit of RNA polymerase (subunits: $\alpha 2$, $\beta, \beta$, and $\omega)$ that has many hot spots for mutations $[20,21$, 55]. Mutation in this gene reduces its binding to rifampicin and thus results in acquisition of rifampicin resistance by E. coli mutants $[20,21,55]$. This assay is advantageous due to its simplicity in deployment, the ability to provide a wide spectrum of forward mutations and low level of spontaneous mutations (approximately $1 / 10^{8}$ cells) (Figure 1 ). It has been extensively used recently to screen the antimutagenic potential of different foods particularly fruits, vegetables and other allied food products at Food Technology Division, Bhabha Atomic Research Centre, Mumbai, India (Figure 2) [20, 5055, 75-79]. The assay is better for scoring antimutagenicity over mutagenicity. This is because $r p o B$ has many hot spots of mutation and hence detecting precise site of mutation due to any mutagenic assault becomes cumbersome. However, for analyzing antimutagenicity this does not create a limiting condition, albeit it provides a comprehensive window to screen the antimutagenic potential.

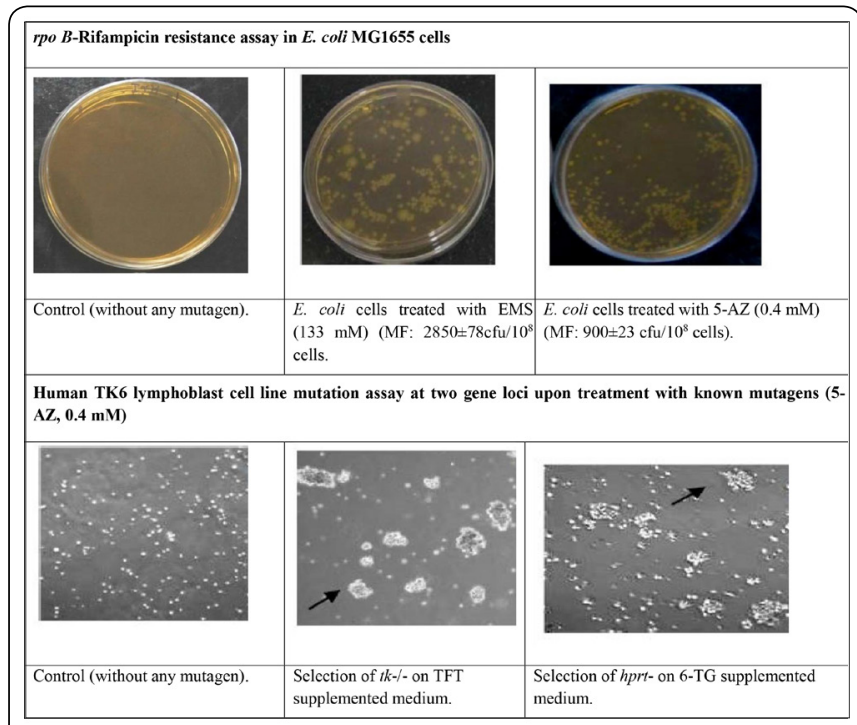

Figure 1: Recently standardized mutagenicity assay systems (MF: Mutation frequency; TFT: Trifluorothymidine; 6-TG: 6-thioguanine).

\section{Vibrio harveyi assay}

The test employs a series of genetically modified Vibrio barveyi strains. The bacterium is naturally sensitive to neomycin; however, antibiotic-resistant mutants may arise. The frequency of appearance of mutants increases in the presence of mutagens in a dose-response manner, which forms the basis of this assay [80-88]. It is also not pathogenic to humans, and hence is safe to work with. This was also found to be significantly more sensitive to mutagenic treatments than E. coli [80]. $V$. harveyi cell envelope is significantly more permeable for large molecules, including most mutagens, and hence penetration of mutagens into $V$. harveyi cells is more efficient relative to many other bacteria used in mutagenic assays [80]. Besides being a tool for mutagenic detection, $V$. harveyi possesses several features making this bacterium a useful bio indicator of mutagenic pollution in natural water samples particularly marine water due to higher level of salt tolerance [81].

\section{Yeast mutagenicity assay}

Yeasts being eukaryotes have chromosome structure and DNA repair processes quite similar to those in mammals. Saccharomyces cerevisiae strains have endogenous cytochrome 
$\mathrm{P} 450$, and therefore, can be very useful testing promutagens [89]. Two assay systems have been described for yeast. One of these detects insertion/deletion mutations and other base substitutions. The assay for insertion/deletion mutations uses a variety of different simple repeats placed in frame with URA3 such that insertions or deletions lead to a selectable Ura (-) phenotype; essentially all such mutations are in the simple repeat sequence. The assay for base substitution mutations uses a series of six strains with different mutations in one essential codon of the CYC1 gene. Because only true reversions lead to a selectable phenotype, the bases mutated in any reversion event are known [90]. Also an "indirect" reporter assay system based on recombinant yeast containing both a sensor and a reporter plasmid has been developed. The sensor plasmid contains a gene encoding the artificial transcription factor of the E. coli LexA DNA binding domain fused to the transcriptional activation domain of yeast Gal4p, which is regulated by the DNA damage-inducible RNR2 promoter. The reporter plasmid contains the $E$. coli lac $Z$ gene with the LexA binding site in the 5'-upstream region, allowing transcriptional activation by the induced LexA-GAL4 protein. To increase the sensitivity of this reporter system amongst several deletion yeast strains enhanced induction of reporter activity was observed in DNA repair-deficient mag1Delta cells [91].

\section{Human lymphoblast mutation (HLM) assay}

The TK6 human lymphoblast cell line contains two widely used selectable markers: the heterozygous $t k$ locus on chromosome $17 \mathrm{q}$ and the X-linked, hemizygous hprt locus. The $t k$ gene is involved in the synthesis of thymidine kinase 1 , a cytosolic phosphotransferase enzyme required in pyrimidine salvage pathway for phosphorylation of deoxythymidine to deoxythymidine 5'-monophosphate (dTMP). It can also phosphorylate pyrimidine analogue such as trifluorothymidine (TFT), which possibly blocks DNA replication upon incorporation, rendering $t k^{-/}$mutants to survive the cytotoxicity. The hprt gene is involved in the synthesis of the enzyme hypoxanthine-guanine phosphoribosyltransferase (HGPRT) having role in purine salvage pathway. HGPRT catalyzes the conversion of hypoxanthine to inosine monophosphate (IMP) and guanine to guanosine monophosphate (GMP) via transfer of the 5-phosphoribosyl group from 5-phosphoribosyl 1-pyrophosphate (PRPP). This enzyme provides an alternative to energy-expensive de novo synthesis of nucleotides by maintaining intracellular purine nucleotide pool in stressed cells. In addition to its normal substrates, HGPRT can also catalyze the transformation of purine analogues such as 6-thioguanine (6-TG) to 6-thioguanine monophosphate (TGMP). Intracellular accumulation of TGMP hampers the de novo synthesis of guanine which is carried out by inosine monophosphate dehydrogenase. TGMP gets phosphorylated to thioguanine diphosphate (TGDP) and thioguanine triphosphate (TGTP). The TGMP, TGDP and TGTP are collectively called 6thioguanine nucleotides (6-TGN). 6-TGN is cytotoxic to cells as it incorporates into DNA biosynthesis leading to strand breakage [92]. However the hprt mutants lacking the functional HGPRT enzyme cannot phosphoribosylate 6-TG and hence these mutant cells are resistant to the cytotoxic effects of 6-TG. For performing the assay the wild type cells $\left(t k^{+/-}\right.$or $\left.h p r t^{+}\right)$are selected in CHAT (cytidine, hypoxanthine, aminopterin and thymidine) medium where aminopterin blocks the de novo synthesis of nucleotides by inhibiting the dihydrofolate reductase enzyme. Cells were further grown in CHT medium (without aminopterin) for preferential enrichment of $t k^{+-}$or $h p r t^{+}$population. This selected cell population is further grown in the presence of test (mutagenic/ antimutagenic) compound and later selected with TFT and 6-thioguanine (6-TG) for $t k^{-/}$and $h p r t^{-}$cells, respectively. Known mutagens are used as positive control. The mutant cells divide and form cellular aggregates (in suspension) through de novo synthesis of nucleotides which can be visualized under an inverted microscope (Figure 1). The result is expressed as the relative number of mutant cells to the total number of seeded cells $[54,77]$.

\section{Drosophila mutagenicity assay}

Mutagen-sensitive (mus) mutations in Drosophila melanogaster render developing flies hypersensitive to the lethal effects of DNA-damaging agents and hence, serve as sensitive in vivo indicators of a wide range of mutagens and genotoxic carcinogens. That assay measures the survival of DNA repairdeficient mus homozygotes relative to their repair-proficient heterozygous siblings. Those two classes of fly are easily distinguished from one another by their phenotypic markers. In addition, the heterozygotes serve as a relatively mutageninsensitive internal control in all test vials. One tester strain (mus208B1 mus210B1 mus211B2) was successfully used in identifying 11 of 12 chemical carcinogens as genotoxic and two noncarcinogens tested as nongenotoxic [93].

\section{Chromosomal abnormalities detection test}

Both structural and numerical changes occurring in chromosomes can be identified in vitro in metaphase spread preparations from mutagen/antimutagen exposed mammalian cells. Common in vitro chromosomal damage tests include the mammalian chromosome aberration test and the micronucleus test. For chromosome aberration test, mammalian metaphase cells are analyzed for the presence of structural chromosome aberrations, whereas in the micronucleus test, micronuclei in the cytoplasm of cultured mammalian cells during interphase are detected. The micronucleus test is a procedure for the detection of both aneuploidy and clastogenicity in cultured mammalian cells $[57,58]$. The in vivo chromosome aberration test in mammals allows the identification of structural chromosome changes induced by a substance in the bone marrow cells of animals, whereas the in vivo micronucleus assay is used for the identification of genetic changes induced by the tested compound to the chromosomes or the mitotic apparatus of cells by the analysis of erythrocytes as sampled in the bone marrow and/or peripheral blood cells of animals.

\section{Fruits and Vegetables as Antimutagens}

There are documented scientific evidences endorsing beneficial role of fruits and vegetables in the prevention as well as treatment of different diseases due to their biologically active substances, such as vitamins and secondary metabolites (polyphenols, carotenoids, sterols, glucosinolates, and saponins [94-103]. Hence, the consumption of fruits and vegetables, which is well below the recommended level, should be 
encouraged. It has been shown that individuals who daily eat five servings or more of fruits and vegetables have approximately half the risk of developing many diseases including a wide variety of cancers, particularly those related to gastrointestinal tract [104]. In some studies, dietary fiber and polyphenols of fruits have been reported to improve lipid metabolism and prevent the oxidation of low density lipoprotein cholesterol (LDL-C), which hinder the development of atherosclerosis [105-107].

\section{Antimutagenic potential of Fruits}

Current research in author's laboratory and many other laboratories in the world has focused on health protective properties including antimutagenic potential of different fruit types and their cultivars. A brief outline on the antimutagenic potential of some common as well as exotic fruits found across the world is reported.

\section{Apple (Malus domestica)}

Worldwide, apple is cultivated as a fruit tree for its sweet and pomaceous fruit. Besides, it is the most widely grown species in the genus Malus. Apple fruits are low in calories and notable for impressive list of phytochemicals, and antioxidants. Studies suggest that its components are essential for optimal growth, development, and overall wellness. In a recent study different apple cultivars were evaluated for their potential health protective attributes such as antimutagenic and antioxidant properties [54]. These functional prophylactic attributes of apples displayed cultivar specificity as cv. 'Granny Smith' displayed significantly higher and broad spectrum antimutagenicity in $E$. coli $r p o B /$ Rif $^{\mathrm{R}}$ assay, whereas, cultivars 'Ambri Kashmiri', 'Kinnaur' and 'Red Delicious' exhibited strong antioxidant activity. As compared to antimutagenicity, the antioxidant and radio protective properties were found to be better correlated than antimutagenicity. Suppression of errorprone DNA repair pathway (such as E. coli SOS response) was found to be one of the possible mechanisms contributing to its antimutagenicity. The phenolic extract of 'Granny Smith' was purified (through HPLC) and the antimutagenic bioactive was identified as procyanidin dimer. Besides, the purified compound also displayed significant antimutagenicity in thymidine kinase locus of human lymphoblast cell line ( $\left.\mathrm{TK}^{-}\right)$ against ethyl methanesulfonate induced mutagenesis.

In an another study, aqueous extract of Apple (Malus domestica 'Golden Delicious') strongly inhibited the mutagenicity of NPYR (N-nitrosopyrrolidone) by $54 \%$ in Ames test at a concentration of $\leq 250 \mu \mathrm{g} /$ plate [108].

\section{Aronia melanocczrpa}

Aronia melanocczrpa is commonly called as 'Black chokeberry'. The anthocyanins isolated from this fruit displayed significant antimutagenicity against benzo[a]pyrene and 2-amino fluorene in the Ames test [109]. Besides, in the sister chromatid exchange test with human blood derived lymphocytes cultured in vitro, a significant decrease of SCEs frequency induced by benzo[a]pyrene was observed in the presence of anthocyanins.

\section{Copaiba (Copaifera langsdorffii)}

Copaifera langsdorffi (copaiba) is an exotic Brazilian fruit.
In a recent study, the antimutagenic potential of this fruit was elucidated and copaiba powder (dose of $100 \mathrm{mg} / \mathrm{kg}$ ) showed great reduction of micronuclei [110].

\section{Dillenia indica}

Dillenia indica (Elephant apple, chulta/chalta or ouu) is a species of Dillenia native to southeastern Asia and produces a large hard fruit. Fruit extract Dillenia indica displayed moderate antimutagenic activity at $1000 \mu \mathrm{g} /$ plate concentration and strong at 1500 and $2000 \mu \mathrm{g} / \mathrm{plate}$ concentrations against sodium azide induced mutation in Salmonella tester strain (TA 1531) [111].

\section{Date fruit}

Fruits of the date palm (Phoenix dactylifera L. Arecaceae) are very commonly consumed in many parts of the world and are a vital component of the diet in most of the Arabian countries. Date fruit extract produced a dose-dependent inhibition of benzo(a)pyrene-induced mutagenicity in Salmonella tester strains TA98 and TA100 (with metabolic activation). Extract from $3.6 \mathrm{mg} /$ plate and $4.3 \mathrm{mg} /$ plate was required for $50 \%$ inhibition of His+ revertant formation in TA98 and TA100, respectively. Antimutagenic activity in date fruit is quite potent and implicates the presence of compounds with potent free-radical-scavenging activity [112].

\section{Eugenia stipitata}

Eugenia stipitata ssp. Sorroria Mcvaugh belongs to Myrtaceae family and is predominantly found in the Amazonian rain forest of Brazil, Colombia and Ecuador. The edible fruit is considered as a rich source of various phytochemicals including terpenes, volatile compounds, fiber, and vitamin $\mathrm{C}$ and is widely known for its functional (high antioxidant activity) and potential health benefits to humans. Antimutagenic and anti-genotoxic activities of the fruit were assessed employing micronucleus test and comet assay in mice, respectively. The ethanolic extract displayed significantly higher antimutagenic and antigenotoxic potential (at concentration of $300 \mathrm{mg} / \mathrm{kg}$ of body weight) thus apparently highlighting its potential preventive effects against cancer [113].

\section{Grape (Vitis vinifera)}

A grape is a fruiting berry of the deciduous woody vines of the botanical genus Vitis. Recently, the strong beneficial health effects of grape flavonoids have been directly connected to the so called "French Paradox". This term refers to the epidemiological observation of comparatively low incidence of coronary heart diseases in the population of the Mediterranean region, despite the presence of a local diet rich in saturated fats. Concord grapes are rich in polyphenolic chemicals and anthocyanin pigments that may have health protective biological properties. In an earlier study it was shown that grape juice consumption could significantly inhibit the initiation stage of 7, 12-dimethylbenz[a]anthracene (DMBA) induced rat (female Sprague-Dawley rats) mammary tumorigenesis. Rats fed with grape juice phenolics displayed significantly lower levels of in vivo mammary DMBA-DNA adduct formation [114]. In another study, the antimutagenic and antigenotoxic potential of grape juice concentrate in rodent organs exposed to cadmium chloride (cadmium chloride at 1.2 
$\mathrm{mg} / \mathrm{kg}$ body weight) when assayed by single cell gel (comet) and micronucleus assays indicated decreased genotoxic effects in peripheral blood and liver cells [115]. Also a decrease in anti-8-hydroxy-20-deoxyguanosine (8-OHdG) expression level in hepatocytes was observed.

\section{Guava}

Psidium guajava (common guava, lemon guava) is a small tree in the Myrtle family (Myrtaceae) and guavas are common tropical fruits cultivated and enjoyed in many tropical and subtropical regions of the world. Fruit is considered to be a rich source of phytonutrients having health benefits. In a study, the water and chloroform extracts of guava were tested for their antimutagenicity [116]. The water extract was effective in inactivating the mutagenicity of direct-acting mutagens, e.g., 4-nitro-O-phenylenediamine, sodium azide, and the S9dependent mutagen, 2-aminofluorene, in the tester strains of S. typhimurium. The chloroform extract was found inactive. The enhanced inhibitory activity of the extracts on pre-incubation suggests the possibility of desmutagens in the extracts. Major constituents were found to be ascorbic and citric acid, however, the role of other antimutagenic factors in the extracts cannot be ruled out.

\section{Jackfruit (Artocarpus heterophyllus Lam)}

Jackfruit (Artocarpus heterophyllus Lam) is a rich source of several high-value compounds with potential beneficial physiological activities. Due to its reported health benefits the consumption of Jackfruit pulp has increased. In a recent study, the pulp of Jackfruit extract was evaluated for its antimutagenic and antiproliferative properties, using $S$. typhimurium tester strains TA98 and TA100 with metabolic activation (S9) and a cancer cell line M12.C3.F6 (murine B-cell lymphoma), respectively [117]. The Jackfruit extract purified fractions were reported to reduce the number of aflatoxin B1 revertants as well as proliferation of M12.C3.F6 cells in a concentration dependent manner, which indicated its health protective and antimutagenic potential.

\section{Java plum (Syzygium cumini)}

Syzygium cumini (Java Plum) belongs to the family Myrtaceae and is believed to have originated in Indian subcontinent. S. cumini fruits have been reported to be rich in flavonoids and anthocyanins. In a study carried out at Food Technology Division, Bhabha Atomic Research Centre, Mumbai, India the antimutagenic potential of 11 commonly consumed fruits in India was analyzed wherein fruits displayed significant variation in antimutagenicity when assayed by E. coli rifampicin resistance $\left(\mathrm{Rif}^{\mathrm{R}}\right)$ assay [52]. Among them, Java plum displayed highest antimutagenicity. Java plum was further selected and characterized for its bioactive compound(s). Anthocyanins were found to be responsible for the observed antimutagenicity and the anthocyanins were further purified by HPTLC. All bands visible on TLC plate showed antioxidant activity whereas, only one band at $\mathrm{R}_{\mathrm{f}} 0.22$ was most antimutagenic and resolved into two peaks in HPLC. The second peak ( $\left.t_{R} 3.8 \mathrm{~min}\right)$ displayed a strong and broad spectrum antimutagenicity which was identified as petunidin-3, 5-diglucoside [52].

\section{Mangaba}

Mangaba (Hancornia speciosa Gomes) is the fruit obtained from mangabeira tree (family Apocynaceae) which is predominantly found in the tropical areas of Brazil. The shape of the fruit is ellipsoidal or spherical berry having sweet and acidic, and the viscous texture. Mangaba fruit pulp has been reported to display protection against doxorubicin and dimethyl hydrazine-induced mutagenicity in male Swiss mice in bone marrow and gut micronucleus test and also apoptosis index [118]. The in vivo tests revealed that mangaba fruit pulp showed no genotoxic effects in any of the assays performed.

\section{Murici (Byrsonima crassifolia)}

The fruit known as murici (Byrsonima crassifolia L., Malpighiaceae) grows on small trees (at the most $5 \mathrm{~m}$ tall) and is found both in the Amazonian region as well as some Northeastern states of Brazil. When mature, it is yellow, has a diameter of 1.5 to $2 \mathrm{~cm}$, and a strong odor resembling a fruity, rancid cheese. Murici, at $400 \mathrm{mg}$ extract $/ \mathrm{kg}$ body weight was found as an effective treatment to protect against genotoxicity and induced mutagenicity. The extract effects of these fruits on the cell, as well as other beneficial roles that they could have on cell metabolism still remains to be elucidated [119].

\section{Noni}

Morinda citrifolia L., "Noni" (Rubiaceae) is an evergreen plant indigenous to Southeast Asia and in traditional Polynesian medicine, Noni has been used to treat variety of diseases for more than 2000 years. Currently, Noni products such as juices and encapsulated powders are popular functional foods in Asia, Europe, and North America. Its juice is already a significant player in the growing functional beverage market and has been accepted as a new food in the European Union, and has been found to be acceptable for human consumption after official safety evaluations. In a recent study, a commercial noni juice was evaluated for its protective activities against the lesions induced by mitomycin C (MMC) and doxorubicin (DXR) using the Somatic Mutation and Recombination Test (SMART) in Drosophila melanogaster. Three-day-old larvae, trans-heterozygous for two genetic markers (mwh and $f(r 3)$, were cotreated with TNJ plus MMC or DXR. A significant reduction in genotoxic effects of MMC and DXR caused by the juice was observed which highlighted its strong antimutagenic potential.

\section{Pomegranate}

Pomegranate is one of the common fruits that is available worldwide and has been used for centuries for the treatment of various ailments. Pomegranate is a rich source of many phenolic compounds including flavonoids and hydrolyzable tannins. Pomegranate seeds are rich in sugars, polyunsaturated fatty acids, vitamins, polysaccharides, polyphenols and minerals and have high antioxidant activity. When crushed and dried, the seeds produce oil with $80 \%$ punicic acid, the 18 -carbon fatty acid, along with the isoflavone genistein, the phytoestrogen coumestrol and the sex steroid estrone. The antimutagenic effect of the bioactive pomegranate compounds has been demonstrated by a decrease in the frequency of genotoxicant induced chromosomal aberrations in bone marrow cells of mice and rats [120]. Recent findings suggest that agents 
derived from pomegranate fruit can effectively interfere with multiple pathways critically involved in different stages of the development and progression of tumors.

\section{Randia echinocarpa}

Randia echinocarpa belongs to Rubiaceae plant predominant in Mexico. The edible fruit is known for its immense ethno pharmacological relevance under various diseased conditions. Its hexane fraction displayed significantly strong antimutagenic activity in S. typhimurium YG1024 through micro suspension assay when 1-nitropyrene was used as mutagen [121]. In this study highest antimutagenicity was attributed to the presence of sterols (predominantly campesterol and $\beta$-sitosterol) and fatty acids (palmitic and linoleic). The samples evaluated did not show any toxicity or mutagenicity.

\section{Vegetables as antimutagen}

Antimutagenic activity of many vegetable juices were earlier studied against mutagenicity induced by 2-amino-3-methyl[4,5-f]-quinoline (IQ), 2-amino-3,4dimethylimidazo[4,5-f] quinoline (MeIQ) or 2-amino3,8dimethylimidazo[4,5-f] quinoxaline (MeIQx) in $S$. typhimurium TA98 and TA100 [122]. Strong antimutagenic activity was displayed by beets, chives, horseradish, onions, rhubarb and spinach. All cruciferous vegetables showed strong to moderate antimutagenic activities, except Chinese cabbage, which displayed weak activity. Moderate antimutagenicity was found with green beans and tomatoes, whereas weak activities in eggplant, garden cress, many lettuces, leeks, mangold, cucumber, pumpkin, radish and summer squash. However, some vegetables such as Asparagus, carrots, fennel leaves, parsley, green pepper and radishe were not found to display any antimutagenicity.

\section{Effect of variety/cultivar}

In a comprehensive study, forty one vegetables were screened along with their common varieties employing Rif ${ }^{R}$ assay in wild type E. coli MG1655 and Ames test at Food Technology Division, Bhabha Atomic Research Centre, Mumbai [50]. Most antimutagenic vegetables were cauliflower, cabbage, pepper (bell-red, hot-red Jalapino, and hot Arbol), eggplant (This, small-violet and green-yellow-striped), garlic, onian (red), Zucchini, Bean (lima, clustered and yardlong), squash, gourd (bottle), cucumber (Madras), pea (green), drumstick, and Indian gooseberry against ultraviolet induced mutagenesis. Effect of cultivar difference in antimutagenic activity was also studied with traditional vegetables cultivated in limited areas near Kyoto [123]. Among those traditional vegetables, Kamo eggplant and Katsura oriental pickling melon, Shishigatani pumpkin showed higher antimutagenicity against UV-induced mutation of E. coli $\mathrm{B} / \mathrm{r}$ WP2 than their corresponding common vegetable. Five different types of Capsicum spp. ('Chilaca', 'Poblano', 'Serrano', 'Jalapeno' and 'Pimiento') were analyzed for antimutagenicity using $S$. typhimurium tester strain YG1024 against 1nitropyrene (1NP), 1,6-dinitropyrine (1,6-DNP), and 1,8-dinitropyrine (1,8DNP). In that study too, varietal effect on antimutagenicity was observed and varieties such 'Chilaca' and 'Pimiento' were found to be comparatively more potent [124].

\section{Mutagen specificity}

Mutagen based variation in antimutagenicity of vegetables has been reported in numerous studies. Hexane and chloroform extracts of Chinese radish strongly inhibited the mutagenicity of both direct acting mutagens (2-(2-furyl)3-(5-nitro-2- furyl) acrylamide and sodium azide) as well as indirect mutagens (aflatoxin B1) but was not found to inhibit the mutagenicity of an indirect acting benzo[a]pyrene [125].

Similarly, aqueous extract of some vegetables such as onion $(500 \mu \mathrm{g} /$ plate) showed 60\% antimutagenicity in Ames test using S. typhimurium TA100 against $\mathrm{N}$-nitrosodimethylamine (NDMA); carrot (250 $\mu \mathrm{g} /$ plate $)$ showed $49 \%$ against $\mathrm{N}$-nitrosodibutylamine (NDBA), and garlic extract $(2000 \mu \mathrm{g} /$ plate) showed $65 \%$ against $\mathrm{N}$-nitrosopiperidine (NPIP) [108].

\section{Effect of mode of cultivation}

In a study, juices of organically cultivated vegetables (using a water-soluble chitosan and leaf surface spray) were compared with generally cultivated vegetables in forward mutation test with S. typhimurium TM677 and 8-azaguanine as a detection agent [126]. Organically cultivated Chinese cabbage, carrot, Welsh onion, and Qing-gen-cai displayed 37-93\% antimutagenicity against 4-nitroquinoline oxide (4NQO), while the generally cultivated ones displayed only 11-65\%. Antimutagenicity of organically cultivated and GC spinach was 78 and 49\%, respectively against 3-amino-1methyl-5H-pyrido[4,3b]indole acetate (Trp-P-2). Similarly, the antimutagenicity of methanol extract from the spring baechu cabbage (Brassica campestris L. ssp pekinensis [Lour.] Rupr.) particularly cultivated by Tunnel method was higher than Noji against mutagenicity induced by MNNG and AFB1 in Ames test [127] and thus indicated effect of cultivation on this bioactivity.

\section{Solvent based variation}

Type of solvent used for extraction of vegetables has been reported to affect the extent of reduction in induced mutagenesis [128]. Interestingly, around $96 \%$ of the $n$-hexane extracts, $64 \%$ of the dichloromethane extracts, $44 \%$ of the acetone extracts, and $36 \%$ of the 2 -propanol extracts of different vegetables displayed antimutagenic activities [128]. In other study, vegetables such as Brussels sprouts, carrot, and yellowred peppers were sequentially solvent extracted with n-hexane, dichloromethane, acetone, and 2-propanol and tested for the inhibition of induced mutagenesis by aflatoxin B1 (AFB1), benzo[a]pyrene $(\mathrm{BaP}), \quad 2$-amino-3-methylimidazo[4,5-f] quinoline (IQ), and cyclophosphamide (CP) using Ames test in S. typhimurium strains [129]. This activity was found in different extracts, but most prevalent in the n-hexane extracts. In another study, aqueous dialysates of most of the vegetables were reported to reduce the mutagenicity of $\operatorname{Trp}-\mathrm{P}-2$ in $S$. typhimurium TA100, whereas only some dialysates of burdock, eggplant, and spinach also inhibited the mutagenicity of Trp-P-1, benzo[a]pyrene, sterigmatocystin, aflatoxin B1, 2-(2-furyl)-3-(5-nitro-2-furyl)-acrylamide and $\mathrm{N}$-methylN'-nitroso-N-nitrosoguanidine [130].

\section{Antimutagenicity evaluation in higher systems}

In a study protective effect of vegetables was assessed against 
the genotoxicity of 2-amino-3methylimidazo[4,5-f] quinoline (IQ) and 2-amino-1-methyl-6- phenylimidazo[4,5-b] pyridine (PhIP) in genetically engineered V79 Chinese hamster fibroblasts using comet assay [131]. Among vegetable juices, spinach and onion juices $\left(\mathrm{IC}_{50}=0.42-0.54 \%\right)$ displayed strong inhibition of IQ genotoxicity whereas broccoli, cauliflower, beet root, sweet pepper, tomato, chard, and redcabbage juices suppressed IQ genotoxicity only moderately, whereas cucumber juice was not effective.

In other study, the mice (C57B1) were placed on diet (AIN-93G) supplemented to dry weight (20\%) with grains or freeze-dried fruits or vegetables and the frequency of micronuclei in the peripheral blood measured [132]. Among foods ( 26) tested, flaxseed was most effective in reducing the incidence of micronuclei by 30 and $11 \%$ in the reticulocyte and normochromatic erythrocyte cell populations, respectively. The antimutagenicity of lettuce and chard extracts against Benzo[a] pyrene was studied in male $\mathrm{Balb} / \mathrm{C}$ mice [133]. The mutagenic activity of the urine samples from only $\mathrm{B}[\mathrm{a}] \mathrm{P}$ groups treated was high than the group treated also with vegetable extracts in Ames test.

Extract of the poblano pepper (Capsicum spp.) was assessed for antimutagenicity against the nitrosation process in wing cells of Drosophila melanogaster using the somatic mutation and recombination test [134]. The poblano juice decreased the mutations per wing by 40 and $80 \%$ as compared to methyl urea $(\mathrm{MU})$ and sodium nitrite (SN), respectively. Some important vegetables having high antimutagenicity have been displayed in Table 3.

Besides certain fruit juices and tea were also analyzed for protective effects using Chinese hamster lung fibroblasts, genetically engineered for the expression of rat cytochrome P450 dependent monooxygenase 1A2 and rat sulfotransferase 1C1 (V79-rCYP1A2-rSULT1C1 cells) against genotoxicity induced by 2-acetylaminofluorene (AAF) or 2-amino-1methyl-6-phenylimidazo[4,5-b]pyridine (PhIP) [135]. Genotoxic activity of PhIP/AAF was strongly reduced by green, black, and rooibos tea, and juices of blueberries, blackberries, red grapes, kiwi, watermelon, parsley, spinach, morellos, and blackcurrants.

\section{Contributing biochemical(s)}

Studies have shown involvement of non-polar, mid-polar or polar group of compounds in observed antimutagenicity depending upon the vegetables.

\section{Non-polar components}

Possible involvement of non-polar compounds of vegetables was indicated in several studies [125, 129, 136]. In those studies, antimutagenicity was reported mainly in $\mathrm{n}$-hexane or chloroform fraction(s). The $\mathrm{n}$-hexane fraction has been reported to contain carotenoids, xanthophylls or carotenol esters in tomato and carrot [129]. Involvement of these phytochemicals ( $\beta$-carotene and xanthophylls) has also been reported in green peppers using $S$. typhimurium tester strain YG1024 against 1-nitropyrene (1-NP), 1,6-dinitropyrine (1,6-DNP), and 1,8-dinitropyrine (1,8DNP) [124]. Antimutagenicity of aqueous and acetone extracts of vegetables against 3-methylcholanthrene and benzo[a]pyrene in the Ames test (gene reversion mutagenesis/ mammalian microsomal activation assay) has also been reported to be correlated with the chlorophyll content [137]. This inhibitory activity of chlorophyll was comparable to the sodium copper chlorophyll in level. In other study too, dietary chlorophyll derivatives showed a dose-dependent inhibitory activity against $\mathrm{B}[\mathrm{a}] \mathrm{P}$ induced mutagenesis in bacterial reverse mutagenicity assay using S. typhimurium TA100 [138].

\section{Mid-polar/polar components}

In a study, thirteen flavonoids and related compounds were reported from spinach which acted as antimutagen against the dietary carcinogen 2-amino-3-methylimidazo [4,5-f] quinoline in S. typhimurium TA 98 [139]. Interestingly, only 5,6,3',4'-tetrahydroxy-7-methoxyflavonol 3-O-disaccharide was reported as potent antimutagen. Several other studies have also demonstrated role of polyphenols in antimutagenicity of vegetables. The antimutagenic profiles and the total soluble phenolic content of the vegetables were reported to be strongly correlated [50]. Polyphenolic from French bean was found to display antimutagenicity against $1-\mathrm{NP}$ and $\mathrm{B}[\mathrm{a}] \mathrm{P}$ and aflatoxin B1 [140,141]. Anthocyanin-rich water fraction and ethyl acetate fraction from Andean purple corn were analyzed against Trp-P-1 in Ames test [142]. Further, ethyl acetate fraction was more potent and its sub-fraction that contained quercetin derivative displayed highest antimutagenic activity.

\section{Components of varying polarity}

In a study with various extracts of eggplant, lutein, pheophorbide or chlorophyllide, and tannins containing sugar-moieties from the $84 \%$ methanol (methanol/water, v/v), 70\% methanol and water, respectively, were reported as possible antimutagens against Trp-P-2 in Ames test [143]. In the same study bioactives such as pheophytin a and $\mathrm{b}, \mathrm{Mg}$ free derivatives of chlorophyll $\mathrm{a}$ and $\mathrm{b}$ were isolated from the petroleum ether layer.

In a recent study, spinach, lettuce, iceberg lettuce, cabbage, broccoli and French bean were comprehensively analyzed for antimutagenicity against ethyl methanesulfonate (EMS) in Rif ${ }^{\mathrm{R}}$ assay in E. coli MG1655 (Kumar et al., unpublished data). In most of these vegetables, phenolics were found to be responsible for antimutagenic activity (Table 4). However, in case of spinach quinone rich extract displayed higher activity than phenolic rich extract (Table 4). The content (yield) of phenolic or quinone rich extract was not found to be correlated to the antimutagenic activity. This indicated that antimutagenic activity of vegetables mainly depends upon the quality of phenolics or quinones.

\section{Possible mechanism of antimutagenicity}

Many mechanisms have been proposed to explain antimutagenicity of vegetables.In Thaivegetables antimutagenic activity against indirect acting mutagens was proposed to be related to the inhibition of the activity of metabolic-activating enzymes in rat liver homogenates [136]. A similar mechanism was proposed for indirect acting mutagens in case of nonpolar fraction of Chinese radish where significant inhibition of rat liver aniline hydroxylase and aminopyrine demethylase was observed [125]. In Andean purple corn, anthocyanin-rich water fraction displayed blocking effect on S-9 mix activation 
Table 3: List of vegetables having high antimutagenic activity in various models.

\begin{tabular}{|c|c|c|c|c|}
\hline Family & Common Name & Scientific Name & Antimutagenicity in various models & Ref. no. \\
\hline \multirow{3}{*}{ Brassicaceae } & Cauliflower & $\begin{array}{l}\text { Brassica oleracea } \\
\text { subsp. Botrytis }\end{array}$ & $\begin{array}{l}\text { S. typhimurium TA98 and TA100; E. coli MG1655 } \\
\text { based Rifampicin resistance }\left(\text { Rif }^{R}\right) \text { assay; V79 Chinese } \\
\text { hamster fibroblasts }\end{array}$ & {$[50,122,131]$} \\
\hline & $\begin{array}{l}\text { Cabbage } \\
\text { (Savoy, red, white, Chinese } \\
\text { and spring baechu etc) }\end{array}$ & $\begin{array}{l}\text { Brassica oleracea } \\
\text { subsp. Capitata }\end{array}$ & $\begin{array}{l}\text { S. typhimurium TA98, TA100, and TM677; E. coli } \\
\text { MG1655 based Rifampicin resistance (Rif }{ }^{2} \text { ) assay; } \\
\text { V79 Chinese hamster fibroblasts }\end{array}$ & {$[50,122,126,127]$} \\
\hline & Broccoli & Brassica oleracea var. italica & $\begin{array}{l}\text { S. typhimurium TA98 and TA100; V79 Chinese } \\
\text { hamster fibroblasts }\end{array}$ & {$[122,131]$} \\
\hline \multirow{3}{*}{ Solanaceae } & $\begin{array}{l}\text { Pepper } \\
\text { (hot Arbol, bell-red, } \\
\text { hot-red Jalapino, sweet, } \\
\text { poblano, green etc) }\end{array}$ & $\begin{array}{l}\text { Capsicum annum } \\
\text { var. grossum }\end{array}$ & $\begin{array}{l}\text { E. coli MG1655 based Rifampicin resistance }\left(\mathrm{Rif}^{\mathrm{R}}\right) \\
\text { assay, S. typhimurium (histidine-deficient) strains, } S \text {. } \\
\text { typhimurium strain YG1024, V79 Chinese hamster } \\
\text { fibroblasts, somatic mutation and recombination test in } \\
\text { wing cells of Drosophila melanogaster, }\end{array}$ & {$[50,124,129,131,134]$} \\
\hline & $\begin{array}{l}\text { Eggplant } \\
\text { (Thai, small-violet, green- } \\
\text { yellow-striped, Kamo etc) }\end{array}$ & Solanum melongena & $\begin{array}{l}\text { S. typhimurium TA98, TA100, E. coli MG1655 based } \\
\text { Rifampicin resistance }\left(\text { Rif }^{\mathrm{R}}\right) \text { assay, E. coli } \mathrm{B} / \mathrm{r} \text { WP2 }\end{array}$ & {$[122,123,130,143]$} \\
\hline & Tomato & Lycopersicon esculentum & $\begin{array}{l}\text { S. typhimurium TA98 and TA100, V79 Chinese } \\
\text { hamster fibroblasts }\end{array}$ & {$[122,129,131]$} \\
\hline \multirow[b]{2}{*}{ Alliaceae } & Garlic & Allium sativum & $\begin{array}{l}\text { S. typhimurium TA100, E. coli MG1655 based } \\
\text { Rifampicin resistance }\left(\text { Rif }^{R}\right) \text { assay }\end{array}$ & {$[50,108]$} \\
\hline & Onion (red etc) & Allium cepa & $\begin{array}{l}\text { S. typhimurium TA98, TA100, TM677, E. coli } \\
\text { MG1655 based Rifampicin resistance }\left(\text { Rif }^{\mathrm{R}}\right) \text { assay, V79 } \\
\text { Chinese hamster fibroblasts }\end{array}$ & {$[50,108,122,126,131]$} \\
\hline \multirow{6}{*}{ Cucurbitaceae } & Gourd (snake) & $\begin{array}{l}\text { Trichosanthes cucumerina } \\
\text { var. anguina }\end{array}$ & E. coli MG1655 based Rifampicin resistance (Rif $\left.{ }^{R}\right)$ assay & [50] \\
\hline & $\begin{array}{l}\text { Pumpkin } \\
\text { (Shishigatani etc) }\end{array}$ & Cucurbita maxima & S. typhimurium TA98 and TA100, E. coli B/r WP2 & {$[50,122,123]$} \\
\hline & Gourd (bottle) & Lageneria siceraria & E. coli MG1655 based Rifampicin resistance (Rif $\left.{ }^{R}\right)$ assay & [50] \\
\hline & Gourd (bitter) & Momordica charantia & S. typhimurium TA100 & {$[160]$} \\
\hline & Cucumber (Madras etc) & Cucumis sativus & E. coli MG1655 based Rifampicin resistance $\left(\right.$ Rif $\left.^{R}\right)$ assay & [50] \\
\hline & Squash & Secbium edule & E. coli MG1655 based Rifampicin resistance (RifR) assay & [50] \\
\hline \multirow[t]{2}{*}{ Fabaceae } & $\begin{array}{l}\text { Bean (French, lima, } \\
\text { clustered, yardlong) }\end{array}$ & $\begin{array}{l}\text { Phaseolus vulgaris, Phaseolus } \\
\text { lanatus, Cyamopsis } \\
\text { tetragonolobus, Vigna ungiculata }\end{array}$ & $\begin{array}{l}\text { E. coli MG1655 based Rifampicin resistance }\left(\mathrm{Rif}^{\mathrm{R}}\right) \\
\text { assay, S. typhimurium strains YG1024, S. typhimurium } \\
\text { strains TA98 and TA100 }\end{array}$ & {$[50,124,141]$} \\
\hline & Pea (green) & Pisum sativum & E. coli MG1655 based Rifampicin resistance (Rif $\left.{ }^{R}\right)$ assay & [50] \\
\hline \multirow[t]{2}{*}{ Amaranthaceae } & Spinach & Spinacea oleracea & $\begin{array}{l}\text { S. typhimurium strains TA98, TA100, TM677, } \\
\text { Chinese hamster lung fibroblasts; V79 Chinese } \\
\text { hamster fibroblasts }\end{array}$ & {$[122,126,131,135,139]$} \\
\hline & Chard & Beta vulgaris & Male Balb/C mice & [133] \\
\hline Asteraceae & Lettuce & Lactuca sativa & Male Balb/C mice & [133] \\
\hline Euphorbiaceae & Gooseberry (Indian) & Phyllanthus emblica & E. coli MG1655 based Rifampicin resistance (Rif $\left.{ }^{R}\right)$ assay & [50] \\
\hline Zingiberaceae & Ginger & Zingiber officinale & E. coli MG1655 based Rifampicin resistance (Rif $\left.{ }^{R}\right)$ assay & [50] \\
\hline Apiaceae & Carrot (red etc) & Daucus carrota & $\begin{array}{l}\text { E. coli MG1655 based Rifampicin resistance }\left(\mathrm{Rif}^{\mathrm{R}}\right) \\
\text { assay; S. typhimurium TA100; S. typhimurium TM677 }\end{array}$ & {$[50,108,122,126,129,131]$} \\
\hline Chenopodiaceae & Beet root & Beta vulgaris & $\begin{array}{l}\text { S. typhimurium TA98 and TA100; V79 Chinese } \\
\text { hamster fibroblasts }\end{array}$ & {$[122,131]$} \\
\hline Moringaceae & Drumstick & Moringa oleifera & E. coli MG1655 based Rifampicin resistance $\left(\mathrm{Rif}^{\mathrm{R}}\right)$ assay & {$[50]$} \\
\hline
\end{tabular}

system of the mutagen, whereas ethyl acetate fraction also displayed Trp-P-1 electrophiles scavenging action [142]. In one study, co-incubation of phenolic extract from Fresh bean and aflatoxin B1 was reported to significantly reduce the mutagenicity and thus the possibility of chemical complex formation was proposed as a mechanism [141]. Antimutagenic effects of vegetable matrices on the activity of pesticides were observed in Ames test and SOS Chromotest [144]. In that study, the antimutagenicity of vegetables was proposed to be related to the antioxidant activity. Antimutagenic activity in broccoli, cauliflower, green beans and tomatoes was proposed to be due to the presence of peroxidase activity in these vegetables [122]. The extract of mixed cruciferous and legume sprouts was reported to reduce $\mathrm{H}_{2} \mathrm{O}_{2}$ induced DNA damage in HT29 cells when analyzed using comet (single cell microgelelectrophoresis) [145].

Antioxidant and antimutagenic activities of vegetables were not found to be well correlated in other study $[50,146]$. However, suppression of SOS repair was proposed as possible mechanism for antimutagenicity of common vegetables as reduced cell-filamentation, cleavage of LexA in wild type $E$. coli cells, and decreased phage induction frequency in an $E$. coli 
Table 4: Antimutagenic activity of different (aqueous, methanolic, total soluble phenolics; and quinones) extracts from some vegetables, and yield of total soluble phenolics and quinones.

\begin{tabular}{|c|c|c|c|c|c|c|c|}
\hline \multirow[b]{2}{*}{ Vegetables } & \multirow[b]{2}{*}{ Plant part } & \multicolumn{4}{|c|}{ Antimutagenic activity $\%$} & \multicolumn{2}{|c|}{ Yield (mg/g dry wt.) } \\
\hline & & Aqueous extract & Methanol extract & $\begin{array}{l}\text { Extract rich in } \\
\text { total soluble } \\
\text { phenolics }\end{array}$ & $\begin{array}{l}\text { Extract rich in } \\
\text { quinones }\end{array}$ & $\begin{array}{l}\text { Extract rich in } \\
\text { total soluble } \\
\text { phenolics }\end{array}$ & $\begin{array}{l}\text { Extract rich in } \\
\text { quinones }\end{array}$ \\
\hline Spinach & Leaf & $66 \pm 3$ & $61 \pm 6$ & $35 \pm 4$ & $72 \pm 6$ & $3.0 \pm 1.1$ & $2.5 \pm 0.6$ \\
\hline Lettuce & Leaf & $63 \pm 3$ & $65 \pm 5$ & $78 \pm 8$ & $2 \pm 1$ & $1.5 \pm 0.9$ & $2.4 \pm 0.9$ \\
\hline Iceberg lettuce & Leaf & $62 \pm 4$ & $48 \pm 3$ & $65 \pm 3$ & $21 \pm 3$ & $0.5 \pm 0.2$ & $2.6 \pm 0.8$ \\
\hline Cabbage & Leaf & $61 \pm 3$ & $41 \pm 4$ & $68 \pm 5$ & $5 \pm 2$ & $2.0 \pm 0.7$ & $1.5 \pm 0.5$ \\
\hline Broccoli & Inflorescence & $58 \pm 5$ & $78 \pm 5$ & $70 \pm 4$ & $11 \pm 3$ & $5.0 \pm 2.1$ & $3.4 \pm 1.0$ \\
\hline French bean & Fruit & $73 \pm 6$ & $88 \pm 6$ & $63 \pm 6$ & $1 \pm 1$ & $1.0 \pm 0.4$ & $1.8 \pm 0.7$ \\
\hline
\end{tabular}

*against ethyl methanesulfonate (EMS) induced mutagenicity at $2 \mathrm{mg} / \mathrm{ml}$ concentration of test extract using E. coli based rifampicin resistance (Rif ${ }^{\mathrm{R}}$ ) assay

strain carrying a defective lambdoid phage (SIVET assay) was observed [51].

Effect of processing of vegetables on their antimutagenic activity

Heating caused a remarkable reduction in antimutagenicity of the juices of beets, cabbage (Chinese, Savoy, red and white), cauliflower, leafy lettuce, cucumber, onions, radish and rhubarb against 2-amino3-methyl [4,5-f]-quinoline (IQ). Brussels sprouts, chicory greens, eggplant, garden cress, mangold, pumpkin, lamb's lettuce and spinach were heat stable [122]. Partial reduction of antimutagenicity due to heating was reported for green beans, kohlrabi, horseradish, tomatoes and chives juices. Later, antimutagenicity of solvent extracts of vegetable was reported to be heat stable and heating caused an increase of antimutagenic potential of some solvent fractions such as of broccoli, white and red cabbage [128]. In other study, boiling was found to significantly affect the antimutagenicity of several vegetables against UV [50]. Apart from peppers (Capsicum) and carrot significant reduction in antimutagenic potential was noted in gourd (snake), pumpkin and cucumber (Madras) of family Cucurbitaceae which indicated heat sensitivity of these bioactive principle(s). Interestingly, heating was found to increase the antimutagenic potential of pepper (bell-red and bell-green), eggplant (long violet), gourds (pointed and Ivy), tomato, and beet. In one study, boiling of various dialysate of vegetables was not found to affect the antimutagenic activity against Trp-P-2 [130]. Sweet corn processed using chlorination, blanching, and gamma radiation was reported to display similar antimutagenic activity similar as of fresh control in Rif ${ }^{\mathrm{R}}$ assay [78]. Thus, most studies have indicated high stability of antimutagenic principle toward different processing.

\section{Antimutagenicity of other Dietary (Allied) Products}

Apart of fruits and vegetables, certain (allied) products have also been reported for antimutagenic properties such as fruit/vegetable products (processed papaya cube), honey, beverages (tea), and specialized ready-to-eat cooked products.

\section{Processed papaya cubes}

Intermediate moisture (IM) papaya cubes (Figure 2) were developed using a novel combination technology which have shelf life of 60 days at ambient temperature whereas, the unprocessed freshly cut samples generally spoil within 2 days. These IM cubes were hygienized by exposing to gamma radiation $(2 \mathrm{kGy})$. Interestingly, in the aqueous extract of the processed papaya, the antimutagenic activity was found to be higher $(\sim 41 \%)$ as compared to unprocessed control $(\sim 18 \%)$ when analyzed using $E$. coli based $\mathrm{Rif}^{\mathrm{R}}$ assay against ethyl methanesulfonate [79].

\section{Honey}

Floral honey demonstrated strong antimutagenicity against physical (UV-C) as well as chemical (ethyl methanesulfonate) mutagens as ascertained by $E$. coli based Rif ${ }^{\mathrm{R}}$ assay and Ames tests [20]. Irradiation (15 kGy) decontaminated the honey, however antimutagenicity of irradiated honey was found to be similar to the non-irradiated control. Honey phenolics contributed to the antimutagenicity of honey. The antimutagenicity of honey was found to be due to the suppression of error-prone repair pathway (as manifested by SOS response) in E. coli. Besides, honey also displayed strong antiproliferative property against different cancer cell lines (myeloid leukemia, breast and lung cancer) but did not affect normal cell line (Int-407, intestinal epithelial cell) indicating its differential and selective cytotoxicity [53]. The findings explained the mechanism of possible therapeutic and prophylactic action of honey against neoplastic changes caused by environmental mutagens and carcinogens.

\section{Beverages from tea leaves and rose-petal}

Green and black tea extracts were reported to have antimutagenicity against MNNG in $E$. coli $\mathrm{B} / \mathrm{r}$ WP2 and $S$. typhimurium TA100 [147]. Both tea extracts were also reported to posses antimutagenicity against PhIP in S. typhimurium TA98 [148]. Aflatoxin B1 (AFB1)-induced chromosome aberrations (consisted mainly gaps and breaks) in rat bone marrow cells was found to be significantly inhibited by tea extract [149]. Tea polyphenols such as gallic acid, methyl gallate, catechins, theaflavins, tanic acid, epigallocatechin (EGC), and epigallocatechin gallate (EGCG), epicatechin gallate 
(ECG) contributed significantly towards antimutagenicity [150]. The antimutagenicity of tea extracts against IQ and Glu-P-1 in S. typhimurium TA 100 showed a significant correlation to the contents of catechins and ascorbic acid, whereas against Trp-P-1 in TA98 or TA100 correlation was high with caffeine contents [151]. Antimutagenic activity of extracts of black tea and green tea was analyzed in in vitro gastrointestinal model, which simulates the conditions in the human digestive tract [152]. In this study, dialysate from the jejunal compartment due to introduction of black and green tea, inhibited the mutagenicity of the food mutagen MeIQx (max. at $2 \mathrm{~h}$ ) in the direct plate assay with S. typhimurium (Ames test). Food matrices were reported to significantly influence the antimutagenic activity of these tea studied. In an antimutagenic study related to petals of rose (Rosa centifolia) cultivars ("passion," "pink noblesse," and "sphinx") by Rif ${ }^{\mathrm{R}}$ assay, the red colored cultivar "passion" displayed highest antimutagenicity and preparation of tea beverage using its petals was not found to affect this activity [55].

\section{Specialized ready to eat (RTE) cooked food}

Food for immune-compromised patients

A nasogastric liquid feed formulation (NGLF) (Figure 2) was developed for immune compromised patients (vulnerable targets of pathogenic assault). NGLF consisted of cereals, pulses, vegetables, and milk powder to provide balanced nutrients. Due to its high water content and rich nutrients, the shelf life was limited up to a few hours only because of microbial contamination and subsequent spoilage. Gamma irradiation at $10 \mathrm{kGy}$ reduced the microbial load of NGLF to non-detectable levels, and the packed and irradiated product could be stored even up to 1 month at $4{ }^{\circ} \mathrm{C}$ without any detectable increase in microbial load. The antimutagenic potential of irradiated NGLF was similar to unprocessed fresh control against ethyl methanesulphonate induced mutagenesis in E. coli cells as evaluated by Rif $^{\mathrm{R}}$ assay [76].

Food for natural calamity victims and other targets

An ambient storable Stuffed Baked Food (SBF) (Figure 2) was developed in India as a ready to eat meal for natural calamity victims and other target groups under a Coordinated Research Project (CRP) of FAO/IAEA by gamma radiation (15 KGy) processing. Mutation analyses in models including human TK6 lymphoblast cell line at genes $t k^{+-}$and $h p r t^{+}$; and bacterial systems [E. coli MG1655 cells (rpoB gene); and Ames strains (TA 100 and TA 102)] endorsed the genotoxic safety of the SBF product. The product displayed similar antimutagenicity as of fresh samples during Rif ${ }^{\mathrm{R}}$ assay, Ames test or mutation assay using TK6 lymphoblast cell line against EMS ans 5-AZ [77]. In Ames test, no mutagenicity induction was observed in high dose ( $25 \mathrm{kGy}$ ) irradiated food 'Kimchi', a Korean food developed and certified as space food [153].

\section{Conclusion and Future Perspectives}

The findings discussed here suggest that there is an utmost need for regular healthy eating habits with plenty of fruits and vegetables to maintain good health, and counteract the unseen challenges caused due to mutagenic exposures from various unknown sources. A close interaction is very much needed

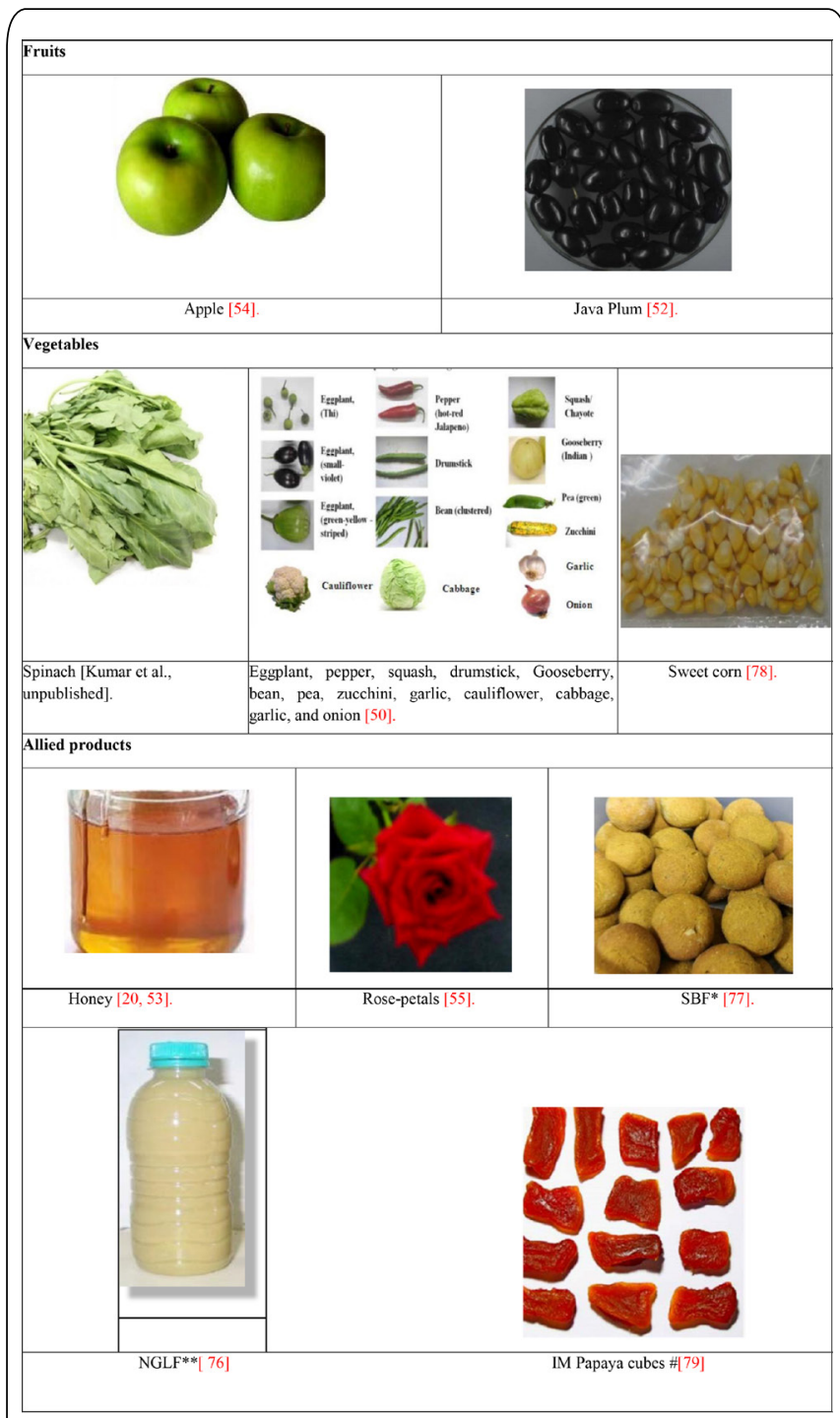

Figure 2: Recent studies reporting antimutageic potential of various fruits, vegetables, and allied products. SBF. (Stuffed Baked Food), a ready to eat meal for natural calamity victims and other target groups; NGLF* (Naso-Gastric liquid food) for immune compromised patient; and IM Papaya cubes\# (Intermediate Moisture papaya cubes as a minimally processed product) developed at Food Technology Division, Bhabha Atomic Research Centre, Mumbai, India.

amongst public-health agencies, state and local governments, schools, the food industry and the media to promote healthy food choices. Also the global demand for more affordable therapeutics and concerns about side effects of commonly used drugs has renewed interest in dietary phytochemicals and traditional complimentary medicines. Use of chemotherapeutic drugs to treat deadly disease like cancer further place challenges to search for the dietary phytochemicals having antimutagenic potency to take care of possible onset of secondary oncogenesis, which is quite frequently encountered possibly due to DNA damage in bystander cells. How to use this scientific knowledge for actual application needs to be worked out. Development of nutraceuticals is one such option where other molecular techniques related to plant tissue culture can be of use to produce the desired compound in sufficient quantity. If the product is a protein coded by a single gene, it can be even produced by genetic engineering approach using suitable host(s). The issue of bioavailability and also the evaluation of 
concentration dependent cytotoxicity need to be addressed before actual application to achieve above said benefits. When such phytochemicals are considered for use within a defined chemotherapeutic framework, their antineoplastic effects need to be assessed in suitable animal models and ultimately in pharmacokinetic and pharmacodynamics pilot studies in human beings. The costs associated with the isolation and development of dietary phytochemicals based therapies could well be lower than those associated with the discovery and development of altogether new chemical entities. These phytochemicals have many molecular targets and are therefore non-specific. Thus, they are dissimilar to molecularly targeted chemotherapeutic agents that are designed to hit only one, or very few, specific targets. This pleiotropism might constitute an advantage, because a complicated disease, such as cancer, is sustained by many oncogenic (i.e., functionally deregulated) events. This review is intended to highlight a comparatively newer but quite relevant thought for researchers working in the area of nutraceuticals and functional foods to utilize the nature's precious gift for the societal health.

\section{Acknowledgements}

Authors acknowledge the help of Dr. Sachin N. Hajare, Dr. Bibhuti B. Mishra, Ms. Nilantana Bandyopadhyay for data related to antimutagenicity in NGLF, IM papaya cubes, and vegetables, respectively, and Ms. Jyoti Verma for HLM assay protocol.

\section{References}

1. Aeschbacher HU, Turesky RJ. 1991. Mammalian cell mutagenicity and metabolism of heterocyclic aromatic amines. Mutat Res 259(3-4): 235250. doi: 10.1016/0165-1218(91)90120-B

2. Ohgaki H, Takayama S, Sugimura T. 1991. Carcinogenicities of heterocyclic amines in cooked food. Mutat Res 259(3-4): 399-410. doi: 10.1016/0165-1218(91)90130-E

3. Lijinsky W. 1999. N-Nitroso compounds in the diet. Mutat Res 443(12): 129-138. doi: 10.1016/S1383-5742(99)00015-0

4. Berghe WV. 2012. Epigenetic impact of dietary polyphenols in cancer chemoprevention: lifelong remodeling of our epigenomes. Pharmacol Res 65(6): 565-576. doi: 10.1016/j.phrs.2012.03.007

5. Migliore L, Coppedè F. 2002. Genetic and environmental factors in cancer and neurodegenerative diseases. Mutat Res 512(2-3): 135-153. doi: 10.1016/S1383-5742(02)00046-7

6. Cooke MS, Evans MD, Dizdaroglu M, Lunec J. 2003. Oxidative DNA damage: mechanisms, mutation, and disease. FASEB J 17(10): 11951214. doi: 10.1096/fj.02-0752rev

7. Ronen A. 1980. 2-Aminopurine. Mutat Res 75(1): 1-47. doi: 10.1016/0165-1110(80)90026-3

8. Weakley SM, Jiang J, Kougias P, Lin PH, Yao Q, et al. 2010. Role of somatic mutations in vascular disease formation. Expert Rev Mol Diagn 10(2): 173-185. doi: 10.1586/erm.10.1

9. Bode AM, Dong Z. 2009. Cancer prevention research - then and now. Nat Rev Cancer 9(7): 508-516. doi: 10.1038/nrc2646

10. Beudot C, De Méo MP, Dauzonne D, Elias R, Laget M, et al. 1998. Evaluation of the mutagenicity and antimutagenicity of forty-two 3-substituted flavones in the Ames test. Mutat Res 417(2-3): 141-153. doi: 10.1016/S1383-5718(98)00103-X

11. Ralhan R, Kaur J. 2007. Alkylating agents and cancer therapy. Expert Opin Ther Pat 17(9): 1061-1075. doi: 10.1517/13543776.17.9.1061

12. Sanderson BJ, Shield AJ. 1996. Mutagenic damage to mammalian cells by therapeutic alkylating agents. Mutat Res 355(1-2): 41-57. doi: 10.1016/0027-5107(96)00021-8

13. Eadie JS, Conrad M, Toorchen D, Topal MD. 1984. Mechanism of mutagenesis by $\mathrm{O}^{6}$-methylguanine. Nature 308(5955): 201-203. doi: $10.1038 / 308201 \mathrm{a} 0$

14. Gulluce M, Agar G, Baris O, Karadayi M, Orhan F, et al. 2010. Mutagenic and antimutagenic effects of hexane extract of some Astragalus species grown in the eastern Anatolia region of Turkey. Phytother Res 24(7): 1014-1018. doi: 10.1002/ptr.3059

15. Hoffmann GR, Calciano MA, Lawless BM, Mahoney KM. 2003. Frameshift mutations induced by three classes of acridines in the lac $Z$ reversion assay in Escherichia coli: potency of responses and relationship to slipped mispairing models. Environ Mol Mutagen 42(2): 111-121. doi: $10.1002 /$ em.10182

16. Novick A, Szilard L. 1952. Anti-mutagens. Nature 170(4335): 926-927. doi: 10.1038/170926a0

17. Kada T, Inoue T, Namiki N. 1982. Environmental desmutagens and antimutagens. In: Klekowski EJ (eds) Environmental mutagenesis and plant biology. Praeger, New York, USA, pp 137-151. doi: 10.1007/ BF02859078

18. Kada T, Shimoi K. 1987. Desmutagens and bio-antimutagens--their modes of action. Bioessays 7(3): 113-116. doi: 10.1002/bies. 950070305

19. De Flora S. 1998. Mechanisms of inhibitors of mutagenesis and carcinogenesis. Mutat Res 402(1-2): 151-158. doi: 10.1016/S00275107(97)00292-3

20. Saxena S, Gautam S, Maru G, Kawle D, Sharma A. 2012. Suppression of error prone pathway is responsible for antimutagenic activity of honey. Food Chem Toxicol 50(3-4): 625-633. doi: 10.1016/j.fct.2012.01.003

21. Kumar S, Gautam S, Sharma A. 2013. Antimutagenic and antioxidant properties of plumbagin and other naphthoquinones. Mutat Res 755(1): 30-41. doi: 10.1016/j.mrgentox.2013.05.007

22. Paolini M, Abdel-Rahman SZ, Sapone A, Pedulli GF, Perocco P, et al. 2003. Beta-carotene: a cancer chemopreventive agent or a co-carcinogen? Mutat Res 543(3): 195-200. doi: 10.1016/S13835742(03)00002-4

23. von Borstel RC, Higgins JA. 1998. Janus carcinogens and mutagens. Mutat Res 402(1-2): 321-329. doi: 10.1016/S0027-5107(97)00312-6

24. Zeiger E. 2003. Illusions of safety: antimutagens can be mutagens, and anticarcinogens can be carcinogens. Mutat Res 543(3): 191-194. doi: 10.1016/S1383-5742(02)00111-4

25. SloczynskaK, Powroznik B, Pekala E, Waszkielewicz AM. 2014. Antimutagenic compounds and their possible mechanisms of action. $J$ Appl Genet 55(2): 273-285. doi: 10.1007/s13353-014-0198-9

26. Tsai SJ, Jenq SN, Lee H. 1996. Naturally occurring diallyl disulfide inhibits the formation of carcinogenic heterocyclic aromatic amines in boiled pork juice. Mutagenesis 11(3): 235-240. doi: 10.1093/ mutage/11.3.235

27. Dion ME, Agler M, Milner JA. 1997. S-allyl cysteine inhibits nitrosomorpholine formation and bioactivation. Nutr Cancer 28(1): 1-6. doi: 10.1080/01635589709514545

28. Ikken Y, Morales P, Martínez A, Marín ML, Haza AI, et al. 1999. Antimutagenic effect of fruit and vegetable ethanolic extracts against $\mathrm{N}$-nitrosamines evaluated by the Ames test. J Agric Food Chem 47: 3257-3264. doi: 10.1021/jf990166n

29. Watanabe M, Kobayashi H, Ohta T. 1994. Rapid inactivation of 3-chloro-4-(dichloromethyl)-5-hydroxy-2(5H)-furanone (MX), a potent mutagen in chlorinated drinking water, by sulfhydryl compounds. Mutat Res 312(2): 131-138. doi: 10.1016/0165-1161(94)90018-3

30. De Flora S, Izzotti A, D'Agostini F, Balansky RM, Noonan D, et al. 2001. Multiple points of intervention in the prevention of cancer and other mutation-related diseases. Mutat Res 480-481: 9-22. doi: 10.1016/S0027-5107(01)00165-8

31. Marnewick JL, Gelderblom WC, Joubert E. 2000. An investigation on 
the antimutagenic properties of South African herbal teas. Mutat Res 471(1-2): 157-166. doi: 1016/S1383-5718(00)00128-5

32. Hour TC, Liang YC, Chu IS, Lin JK. 1999. Inhibition of eleven mutagens by various tea extracts, (-) epigallocatechin-3-gallate, gallic acid and caffeine. Food Chem Toxicol 37(6): 569-579. doi: 10.1016/ S0278-6915(99)00031-9

33. Ozturkcan SA, Turhan K, Turgut Z, Karadayi M, Gulluce M. 2012. Antigenotoxic properties of two newly synthesized $\beta$-aminoketones against $\mathrm{N}$-methyl-N'-nitro-N-nitrosoguanidine and 9-aminoacridineinduced mutagenesis. J Biochem Mol Toxicol 26(7): 258-263. doi: $10.1002 /$ jbt.21414

34. Turhan K, Ozturkcan SA, Turgut Z, Karadayi M, Gulluce M. 2012. Protective properties of five newly synthesized cyclic compounds against sodium azide and $\mathrm{N}$-methyl-N'-nitro-N-nitrosoguanidine genotoxicity. Toxicol Ind Health 28(7): 605-613. doi: 10.1177/0748233711416954

35. Kaur S, Kumar S, Kaur P, Chandel M. 2010. Study of antimutagenic potential of phytoconstituents isolated fromTerminalia arjuna in the Salmonella/microsome assay. Am J Biomed Sci 2(2): 164-177. doi: 10.5099/aj100200164

36. Lee KW, Bode AM, Dong Z.2011. Molecular targets of phytochemicals for cancer prevention. Nat Rev Cancer 11(3): 211-218. doi: 10.1038/ nrc3017

37. Shay KP, Moreau RF, Smith EJ, Smith AR, Hagen TM. 2009. Alphalipoic acid as a dietary supplement: molecular mechanisms and therapeutic potential. Biochim Biophys Acta 1790(10): 1149-1160. doi: 10.1016/j.bbagen.2009.07.026

38. Tian YF, Hsieh CH, Hsieh YJ, Chen YT, Peng YJ, et al. 2012. $\alpha$-Lipoic acid prevents mild portal endotoxaemia-induced hepatic inflammation and $\beta$ cell dysfunction. Eur J Clin Invest 42(6): 637-648. doi: $10.1111 / j .1365-2362.2011 .02630 . x$

39. Evans JL, Goldfine ID. 2000. Alpha-lipoic acid: a multifunctional antioxidant that improves insulin sensitivity in patients with type 2 diabetes. Diabetes Technol Ther 2(3): 401-413. doi: 10.1089/15209150050194279

40. Cai X, Chen X, Wang X, Xu C, Guo Q, et al. 2013. Pre-protective effect of lipoic acid on injury induced by $\mathrm{H}_{2} \mathrm{O}_{2}$ in IPEC-J2 cells. Mol Cell Biochem 378(1-2): 73-81. doi: 10.1007/s11010-013-1595-9

41. Rochette L, Ghibu S, Richard C, Zeller M, Cottin Y, et al. 2013. Direct and indirect antioxidant properties of $\alpha$ lipoic acid and therapeutic potential. Mol Nutr Food Res 57(1): 114-125. doi: 10.1002/ mnfr.201200608

42. Unal F, Taner G, Yuzbasioglu D, Yilmaz S. 2013. Antigenotoxic effect of lipoic acid against mitomycin-C in human lymphocyte cultures. Cytotechnology 65(4): 553-565. doi: 10.1007/s10616-012-9504-8

43. Agar G, Gulluce M, Aslan A, Bozari S, Karadayi M, Orhan F. 2010. Mutation preventive and antigenotoxic potential of methanol extracts of two natural lichen. J Med Plant Res 4(20): 2132-2137.

44. Kotan E, Alpsoy L, Anar M, Aslan A, Agar G. 2011. Protective role of methanol extract of Cetrariaislandica (L.) against oxidative stress and genotoxic effects of $\mathrm{AFB}_{1}$ in human lymphocytes in vitro. Toxicol Ind Health 27(7): 599-605. doi: 10.1177/0748233710394234

45. Nardemir G, Yanmis D, Alpsoy L, Gulluce M, Agar G, et al. 2013. Genotoxic, antigenotoxic and antioxidant properties of methanol extracts obtained from Peltigera horizontalis and Peltigera praetextata. Toxicol Ind Health 31(7): 602-613. doi: 10.1177/0748233713480207

46. Chatti IB, Boubaker J, Skandrani I, Bhouri W, Ghedira K, et al. 2011. Antioxidant and antigenotoxic activities in Acacia salicina extracts and its protective role against DNA strand scission induced by hydroxyl radical. Food Chem Toxicol 49(8): 1753-1758. doi: 10.1016/j. fct.2011.04.022

47. Roy SS, Chakraborty P, Ghosh P, Ghosh S, Biswas J, et al. 2012. Influence of novel naphthalimide-based organoselenium on genotoxicity induced by an alkylating agent: the role of reactive oxygen species and selenoenzymes. Redox Rep 17(4): 157-166. doi: $10.1179 / 1351000212$ Y.0000000018
48. Zhang J, Tian Q, Chan SY, Chuen Li S, Zhou S, et al. 2005. Metabolism and transport of oxazaphosphorines and the clinical implications. Drug Metab Rev 37(4): 611-703. doi: 10.1080/03602530500364023

49. El-Sayed WM, Hussin WA. 2013. Antimutagenic and antioxidant activity of novel 4-substituted phenyl-2,2'-bichalcophenes and azaanalogs. Drug Des Devel Ther 7: 73-81. doi: 10.2147/DDDT.S40129

50. Bandyopadhyay N, Gautam S, Sharma A. 2013. Variety-based variation in the antimutagenic potential of various vegetables and lack of its correlation with their antioxidant capacity. Int J Food Sci Nutr 64(5): 587-598. doi: 10.3109/09637486.2013.763913

51. Bandyopadhyay N, Gautam S, Sharma A. 2014. Suppression of SOS repair in E. coli: possible mechanism of antimutagenicity and protective effects of common vegetables. Int J Food Sci Nutr 65(2): 251-258. doi: 10.3109/09637486.2013.854740

52. Saxena S, Gautam S, Sharma A. 2013. Comparative evaluation of antimutagenicity of commonly consumed fruits and activity-guided identification of bioactive principles from the most potent fruit, Java plum (Syzygium cumini). J Agric Food Chem 61(42): 10033-10042. doi: 10.1021/jf403005x

53. Saxena S, Maurya DK, Gautam S, Sharma A. 2014. Effect of radiation hygienization of honey on its health protective properties. Food Bioscience 8: 14-21. doi: 10.1016/j.fbio.2014.10.002

54. Saxena S, Verma J, Gautam S. 2016. Potential prophylactic properties of apple and characterization of potent bioactive from cv. "Granny Smith' displaying strong antimutagenicity in models including human lymphoblast $\mathrm{TK}^{+/}{ }^{+-}$cell line. J Food Sci 81(2): 508-518. doi: 10.1111/1750-3841.13190

55. Kumar S, Gautam S, Sharma A. 2013. Identification of antimutagenic properties of anthocyanins and other polyphenols from rose (Rosa centifolia) petals and tea.J Food Sci 78(6): H948-954. doi: 10.1111/17503841.12135

56. Parvathy KS, Negi PS, Srinivas P. 2010. Curcumin-amino acid conjugates: synthesis, antioxidant and antimutagenic attributes. Food Chem 120(2): 523-530. doi: 10.1016/j.foodchem.2009.10.047

57. Combes R, Grindon C, Cronin MT, Roberts DW, Garrod J. 2007. Proposed integrated decision-tree testing strategies for mutagenicity and carcinogenicity in relation to the EU REACH legislation. Altern Lab Anim 35(2): 267-287.

58. Eastmond DA, Hartwig A, Anderson D, Anwar WA, Cimino MC, et al. 2009. Mutagenicity testing for chemical risk assessment: update of the WHO/IPCS Harmonized Scheme. Mutagenesis 24(4): 341-349. doi: 10.1093/mutage/gep014

59. Valdiglesias V, Pásaro E, Méndez J, Laffon B. 2010. In vitro evaluation of selenium genotoxic, cytotoxic, and protective effects: a review. Arch Toxicol 84(4): 337-351. doi: 10.1007/s00204-009-0505-0

60. Johnson GE. 2012. Mammalian cell HPRT gene mutation assay: test methods. Methods Mol Biol 817: 55-67. doi: 10.1007/978-1-61779421-6_4

61. De Flora S, Bronzetti G, Sobels FH. 1992. Assessment of antimutagenicity and anticarcinogenicity. Mutat Res 267(2): 153-155. doi: 10.1016/0027-5107(92)90059-B

62. Verhofstad N, Linschooten JO, van Benthem J, Dubrova YE, van Steeg $\mathrm{H}$, et al. 2008. New methods for assessing male germ line mutations in humans and genetic risks in their offspring. Mutagenesis 23(4): 241-247. doi: 10.1093/mutage/gen022

63. Maron DM, Ames BN. 1983. Revised methods for the Salmonella mutagenicity test. Mutat Res 113(3-4): 173-215. doi: 10.1016/01651161(83)90010-9

64. Mortelmans K, Zeiger E. 2000. The Ames Salmonella/microsome mutagenicity assay. Mutat Res 455: 29-60.

65. Bridges BA. 1980. The fluctuation test. Biomedical and Life Sciences 46: 41-44.

66. Ames BN, Durston WE, Yamasaki E, Lee FD. 1973. Carcinogens are mutagens: A simple test system combining liver homogenates for 
activation and bacteria for detection. Proc Natl Acad Sci 70(8): 22812285.

67. Ames BN. 1979. Identifying environmental chemicals causing mutations and cancer. Science 204(4393): 587-593. doi: 10.1126/ science. 373122

68. McCann J, Choi E, Yamasaki E, Ames BN. 1975. Detection of carcinogens as mutagens in the Salmonella/microsome test: assay of 300 chemicals. Proc Natl Acad Sci U S A 72(12): 5135-5139.

69. Luria SE, Delbrück M. 1943. Mutations of bacteria from virus sensitivity to virus resistance. Genetics 28(6): 491-511.

70. Mortelmans K, Riccio ES. 2000. The bacterial tryptophan reverse mutation assay with Escherichia coli WP2. Mutat Res 455(1-2): 61-69. doi: 10.1016/S0027-5107(00)00076-2

71. Bridges BA, Dennis RE, Munson RJ. 1967. Differential induction and repair of ultraviolet damage leading to true reversions and external suppressor mutations of an ochre codon in Escherichia coli B-r WP2. Genetics 57: 897-908.

72. Osborn M, Person S. 1967. Characterization of revertants of $E$. coli WU36-10 and WP2 using amber mutants and an ochre mutant of bacteriophage T4. Mutat Res 4(4): 504-507. doi: 1016/00275107(67)90013-9

73. Green $\mathrm{MH}$, Muriel WJ. 1976. Mutagen testing using $\mathrm{TRP}^{+}$reversion in Escherichia coli. Mutat Res 38(1): 3-32. doi: 10.1016/01651161(76)90076-5

74. Quillardet P, de Bellecombe C, Hofnung M. 1985. The SOS Chromotest, a colorimetric bacterial assay for genotoxins: validation study with 83 compounds. Mutat Res 147(3): 79-95. doi: 10.1016/01651161(85)90021-4

75. Gautam S, Kalidindi R, Humayun MZ. 2012. SOS induction and mutagenesis by dnaQ missense alleles in wild type cells. Mutat Res 735(1-2): 46-50. doi: 10.1016/j.mrfmmm.2012.05.004

76. Hajare SN, Gautam S, Nair AB, Sharma A. 2014. Formulation of a nasogastric liquid feed and shelf-life extension using gamma radiation. J Food Prot 77(8): 1308-1316. doi: 10.4315/0362-028X.JFP-13-458

77. Kumar S, Saxena S, Verma J, Gautam S. 2016. Development of ambient storable meal for calamity victims and other targets employing radiation processing and evaluation of its nutritional, organoleptic, and safety parameters. LWT - Food Sci Technol 69: 409-416. doi: 10.1016/j. lwt.2016.01.059

78. Kumar S, Gautam S, Sharma A. 2015. Hurdle technology including chlorination, blanching, packaging and irradiation to ensure safety and extend shelf life of shelled sweet corn kernels. Journal of Food Processing and Preservation 39(6): 2340-2347. doi: 10.1111/jfpp.12481

79. Mishra BB, Gautam S, Chander R, Sharma A. 2015. Characterization of nutritional, organoleptic and functional properties of intermediate moisture shelf stable ready-to-eat Carica papaya cubes. Food Biosci 10(1): 69-79. doi: 10.1016/j.fbio.2015.02.001

80. Czyz A, Jasiecki J, Bogdan A, Szpilewska H, Wegrzyn G. 2000. Genetically modified Vibrio harveyi strains as potential bioindicators of mutagenic pollution of marine environments. Appl Environ Microbiol 66(2): 599-605. doi: 10.1128/AEM.66.2.599-605.2000

81. Czyz A, Szpilewska H, Dutkiewicz R, Kowalska W, BiniewskaGodlewska A, et al. 2002. Comparison of the Ames test and a newly developed assay for detection of mutagenic pollution of marine environments. Mutat Res 519(1-2): 67-74. doi: 10.1016/S13835718(02)00112-2

82. Piosik J, Ulanowska K, Gwizdek-Wisniewska A, Czyz A, Kapuscinski $\mathrm{J}$, et al. 2003. Alleviation of mutagenic effects of polycyclic aromatic agents (quinacrine mustard, ICR-191 and ICR-170) by caffeine and pentoxifylline. Mutat Res 530(1-2): 47-57. doi: 10.1016/S00275107(03)00136-2

83. Wegrzyn G, Czyz A. 2003. Detection of mutagenic pollution of natural environment using microbiological assays. J Appl Microbiol 95(6): 11751181. doi: 10.1046/j.1365-2672.2003.02121.x
84. Podgórska B, Chec E, Ulanowska K, Wegrzyn G. 2005. Optimisation of the microbiological mutagenicity assay based on genetically modified Vibrio harveyi strains. J Appl Genet 46(2): 241-246.

85. Ulanowska K, Wegrzyn G. 2006. Mutagenic activity of 1-methyl-4phenyl-1,2,3,6-tetrahydropyridine. J Appl Genet 47(1): 85-87. doi: 10.1007/BF03194604

86. Słoczyńska K, Pekala E, Wajda A, Wegrzyn G, Marona H. 2010. Evaluation of mutagenic and antimutagenic properties of some bioactive xanthone derivatives using Vibrio harveyi test. Lett Appl Microbiol 50(3): 252-257. doi: 10.1111/j.1472-765X.2009.02781.x

87. Kamiński K, Obniska J, Chlebek I, Liana P, Pękala E. 2013. Synthesis and biological properties of new N-Mannich bases derived from 3-methyl-3-phenyl- and 3,3-dimethyl-succinimides. Eur J Med Chem 66: 12-21. doi: 10.1016/j.ejmech.2013.05.011

88. Pękala E, Liana P, Kubowicz P, Powroźnik B, Obniska J, et al. 2013. Evaluation of mutagenic and antimutagenic properties of new derivatives of pyrrolidine-2,5-dione with anti-epileptic activity, by use of the Vibrio harveyi mutagenicity test. Mutat Res 758(1-2): 18-22. doi: 10.1016/j.mrgentox.2013.07.011

89. Zimmermann FK, Kern R, Rasenberg H. 1975. A yeast strain for simultaneous detection of induced mitotic crossing over, mitotic gene conversion and reverse mutation. Mutat Res 28(3): 381-388. doi: $10.1016 / 0027-5107(75) 90232-8$

90. Crouse GF. 2000. Mutagenesis assays in yeast. Methods 22(2): 116-119. doi: 10.1006/meth.2000.1051

91. Ichikawa K, Eki T. 2006. A novel yeast-based reporter assay system for the sensitive detection of genotoxic agents mediated by a DNA damage-inducible LexA-GAL4 protein. J Biochem 139(1): 105-112. doi: $10.1093 / \mathrm{jb} / \mathrm{mvj} 011$

92. Karran P, Attard N. 2008. Thiopurines in current medical practice: molecular mechanisms and contributions to therapy-related cancer. Nat Rev Cancer 8(1): 24-36. doi: 10.1038/nrc2292

93. Henderson DS, Grigliatti TA. 1992. A rapid somatic genotoxicity assay in Drosophila melanogaster using multiple mutant mutagen-sensitive (mus) strains. Mutagenesis 7(6): 399-405. doi: 10.1093/mutage/7.6.399

94. Kris-Etherton PM, Hecker KD, Bonanome A, Coval SM, Binkoski $\mathrm{AE}$, et al. 2002. Bioactive compounds in foods: their role in the prevention of cardiovascular disease and cancer. Am J Med 113 Suppl 9B: 71S-88S. doi: 10.1016/S0002-9343(01)00995-0

95. Lim YY, Lim TT, Tee JJ. 2007. Antioxidant properties of several tropical fruits: a comparative study. Food Chem 103(3): 1003-1008. doi: 10.1016/j.foodchem.2006.08.038

96. Luximon-Ramma A, Bahorun T, Crozier A. 2003. Antioxidant actions and phenolic and vitamin $\mathrm{C}$ contents of common Mauritian exotic fruits.J Sci Food Agric 83(5): 496-502. doi: 10.1002/jsfa.1365

97. Paganga G, Miller N, Rice-Evans CA. 1999. The polyphenolic content of fruit and vegetables and their antioxidant activities. What does a serving constitute? Free Radic Res 30(2): 153-162. doi: 10.1080/10715769900300161

98. Proteggente AR, Pannala AS, Paganga G, Van Buren L, Wagner E, et al. 2002. The antioxidant activity of regularly consumed fruit and vegetables reflects their phenolic and vitamin $\mathrm{C}$ composition. Free Rad Res 36(2): 217-233. doi: 10.1080/10715760290006484

99. Alothman M, Bhat R, Karim AA. 2009. Antioxidant capacity and phenolic content of selected tropical fruits from Malaysia, extracted with different solvents. Food Chem 115(3): 785-788. doi: 10.1016/j. foodchem.2008.12.005

100.Cassileth B. 2008. Complementary therapies, herbs, and other OTC agents. Oncology (Williston Park) 22(10): 1202.

101.Xu M, Deng Z, Li M, Li J, Fu H, et al. 2004. Chemical constituents from the mangrove plant, Aegicerascorniculatum.J Nat Prod 67(5): 762766. doi: $10.1021 / \mathrm{np} 030477 \mathrm{z}$

102. Yang J, Paulino R, Janke-Stedronsky S, Abawi F. 2007. Free-radical- 
scavenging activity and total phenols of noni (Morinda citrifolia L.) juice and powder in processing and storage. Food Chem 102(1): 302-308. doi: 10.1016/j.foodchem.2006.05.020

103.Yuka I, Yumiko K, Miyo N, Takashi K. 2003. Antioxidative activity of tropical fruit, Feijoasellowiana berg. Nippon Kasei Gakkaishi 54(11): 945-949. doi: 10.11428/jhej1987.54.945

104.Gescher A, Pastorino U, Plummer SM, Manson MM. 1998. Suppression of tumour development by substances derived from the diet--mechanisms and clinical implications. Br J Clin Pharmacol 45(1): 1-12. doi: $10.1046 /$ j.1365-2125.1998.00640.x

105.Gorinstein S, Bartnikowska E, Kulasek G, Zemser M, Trakhtenberg S. 1998. Dietary persimmon improves lipid metabolism in rats fed diets containing cholesterol. J Nutr 128(11): 2023-2027.

106. Gorinstein S, Kulasek G, Bartnikowska E, Leontowicz M, Morawiec M, et al. 1998. The influence of persimmon peel and persimmon pulp on the lipid metabolism and antioxidant activity of rats fed cholesterol. J Nutr Biochem 9(4): 223-227. doi: 10.1016/S0955-2863(98)00003-5

107.Gorinstein S, Zemser M, Haruenkit R, Chuthakorn R, Grauer F, et al. 1999. Comparative content of total polyphenols and dietary fiber in tropical fruits and persimmon. J Nutr Biochem 10(6): 367-371. doi: 10.1016/S0955-2863(99)00017-0

108. Ikken Y, Cambero I, Marín ML, Martínez A, Haza AI, Morales P. et al. 1998. Antimutagenic effect of fruit and vegetable aqueous extracts against N-nitrosamines evaluated by the Ames test. J Agric Food Chem 46(12): 5194-5200. doi: $10.1021 / \mathrm{j} 9980657 \mathrm{~s}$

109.Gasiorowski K, Szyba K, Brokos B, Kołaczyńska B, JankowiakWłodarczyk M, et al. 1997. Antimutagenic activity of anthocyanins isolated from Aronia melanocarpa fruits. Cancer Lett 119(9): 37-46. doi: 10.1016/S0304-3835(97)00248-6

110.Batista ÂG, Ferrari AS, da Cunha DC, da Silva JK, Cazarin CB, et al. 2016. Polyphenols, antioxidants, and antimutagenic effects of Copaiferalangsdorffii fruit. Food Chem 197(Pt B): 1153-1159. doi: 10.1016/j.foodchem.2015.11.093

111.Jaiswal S, Mansa N, Prasad MSP, Jena BS, Negi PS. 2014. Antibacterial and antimutagenic activities of Dilleniaindica extracts. Food Bioscience 5: 47-53. doi: 10.1016/j.fbio.2013.11.005

112.Vayalil PK. 2002. Antioxidant and antimutagenic properties of aqueous extract of date fruit (Phoenix dactylifera L. Arecaceae). J Agric Food Chem 50(3): 610-617. doi: 10.1021/jf010716t

113.Neri-Numa IA, Carvalho-Silva LB, Morales JP, Malta LG, Muramoto MT, et al. 2013. Evaluation of the antioxidant, antiproliferative and antimutagenic potential of araçá-boi fruit (Eugenia stipitata Mc VaughMyrtaceae) of the Brazilian Amazon Forest. Food Res Int 50: 70-76. doi: 10.1016/j.foodres.2012.09.032

114.Jung KJ, Wallig MA, Singletary KW. 2006. Purple grape juice inhibits 7,12-dimethylbenz[a]anthracene (DMBA)-induced rat mammary tumorigenesis and in vivo DMBA-DNA adduct formation. Cancer Lett 233(2): 279-288. doi: 10.1016/j.canlet.2005.03.020

115.de Moura CF, Ribeiro FA, de Jesus GP, da Silva VH, Oshima CT, et al. 2014. Antimutagenic and antigenotoxic potential of grape juice concentrate in blood and liver of rats exposed to cadmium. Environ Sci Pollut Res Int 21: 13118-13126. doi: 10.1007/s11356-014-3257-1

116. Grover IS, Bala S. 1993. Studies on antimutagenic effects of guava (Psidium guajava) in Salmonella typhimurium. Mutat Res 300(1): 1-3. doi: 10.1016/0165-1218(93)90133-X

117.Ruiz-Montañez G, Hernández AB, Calderón-Santoyo M, López-Saiz CM, Velázquez-Contreras CA, et al. 2015. Screening antimutagenic and antiproliferative properties of extracts isolated from Jackfruit pulp (Artocarpus heterophyllus Lam). Food Chem 175: 409-416. doi: 10.1016/j. foodchem.2014.11.122

118.de Lima JP, Azevedo L, de Souza NJ, Nunes EE, de Barros Vilas Boas EV. 2015. First evaluation of the antimutagenic effect of mangaba fruit in vivo and its phenolic profile identification. Food Res Int 75: 216-224. doi: 10.1016/j.foodres.2015.05.045
119.Malta LG, Ghiraldini FG, Reis R, Maysa do Vale Oliveira, Luciano Bruno Silva, et al. 2012. In vivo analysis of antigenotoxic and antimutagenic properties of two Brazilian Cerrado fruits and the identification of phenolic phytochemicals. Food Res Int 49(1): 604-611. doi: 10.1016/j.foodres.2012.07.055

120.Alekperov UK. 2002. Plant antimutagens and their mixtures in inhibition of genotoxic effects of xenobiotics and aging processes. Eur J Cancer Prev 11 Suppl 2: S8-11.

121.Cano-Campos MC, Díaz-Camacho SP, Uribe-Beltrán MJ, LópezAngulo G, Montes-Avila J, et al. 2011. Bio-guided fractionation of the antimutagenic activity of methanolic extract from the fruit of Randiaechinocarpa (Sessé et Mociño) against 1-nitropyrene. Food Res Int 44(9): 3087-3093. doi: 10.1016/j.foodres.2011.08.006

122.Edenharder R, Kurz P, John K, Burgard S, Seeger K. 1994. In vitro effect of vegetable and fruit juices on the mutagenicity of 2-amino-3methylimidazo[4,5-f] quinoline, 2-amino-3,4-dimethylimidazo[4,5-f] quinoline and 2-amino-3,8-dimethylimidazo[4,5-f]quinoxaline. Food Chem Toxicol 32(5): 443-459. doi: 10.1016/0278-6915(94)90042-6

123.Nakamura Y, Suganuma E, Kuyama N, Sato K, Ohtsuki K. 1998. Comparative bio-antimutagenicity of common vegetables and traditional vegetables in Kyoto. Biosci Biotechnol Biochem 62(6): 11611165. doi: 10.1271/bbb.62.1161

124.Gonzáez de Mejía E, Quintanar-Hernández A, Loarca-Piña G. 1998. Antimutagenic activity of carotenoids in green peppers against some nitroarenes. Mutat Res 416(1-2): 11-19. doi: 10.1016/S13835718(98)00070-9

125.Rojanapo W, Tepsuwan A. 1993. Antimutagenic and mutagenic potentials of Chinese radish. Environ Health Perspect 101 Suppl 3: 247252. doi: $10.2307 / 3431733$

126.Ren H, Endo H, Hayashi T. 2001. The superiority of organically cultivated vegetables to general ones regarding antimutagenic activities. Mutat Res 496(1-2): 83-88. doi: 10.1016/S1383-5718(01)00229-7

127.Chun HK, Kim BK, Park HJ, Cho SM, Kim SN, et al. 2008. Antimutagenic and anticancer effects of baechu cabbage-enhanced functionality of baechu cabbage cultivating by tunnel method. Cancer Prevention Research 13: 122-129.

128.Edenharder R, Leopold C, Kries M. 1995. Modifying actions of solvent extracts from fruit and vegetable residues on 2-amino3-methylimidazo[4,5-f]quinoline (IQ) and 2-amino-3,4dimethylimidazo[4,5-f]quinoxaline (MeIQx) induced mutagenesis in Salmonella typhimurium TA 98. Mutat Res 341(4): 303-318. doi: 10.1016/0165-1218(95)90101-9

129. Rauscher R, Edenharder R, Platt KL. 1998. In vitro antimutagenic and in vivo anticlastogenic effects of carotenoids and solvent extracts from fruits and vegetables rich in carotenoids. Mutat Res 413(2): 129-142. doi: 10.1016/S1383-5718(98)00017-5

130.Shinohara K, Kuroki S, Miwa M, Kong ZL, Hosoda H. 1988. Antimutagenicity of dialyzates of vegetables and fruits. Agric Biol Chem 52(6): 1369-1375. doi: 10.1271/bbb1961.52.1369

131.Platt KL, Edenharder R, Aderhold S, Muckel E, Glatt H. 2010. Fruits and vegetables protect against the genotoxicity of heterocyclic aromatic amines activated by human xenobiotic-metabolizing enzymes expressed in immortal mammalian cells. Mutat Res 703(2): 90-98. doi: 10.1016/j. mrgentox.2010.08.007

132.Trentin GA, Moody J, Torous DK, Thompson LU, Heddle JA. 2004. The influence of dietary flaxseed and other grains, fruits and vegetables on the frequency of spontaneous chromosomal damage in mice. Mutat Res 551(1-2): 213-222. doi: 10.1016/j.mrfmmm.2004.04.005

133.Pèrez A, Gago G. 1991. Antimutagenic activity of lettuce and chard extracts. Nahrung 35(4): 369-371. doi: 10.1002/food.19910350413

134.Ramirez-Victoria P, Guzman-Rincon J, Espinosa-Aguirre JJ, MurilloRomero S. 2001. Antimutagenic effect of one variety of green pepper (Capsicum spp.) and its possible interference with the nitrosation process. Mutat Res 496(1-2): 39-45. doi: 10.1016/S1383-5718(01)00217-0 
135.Edenharder R, Sager JW, Glatt H, Muckel E, Platt KL. 2002. Protection by beverages, fruits, vegetables, herbs, and flavonoids against genotoxicity of 2-acetylaminofluorene and 2-amino-1-methyl-6phenylimidazo[4,5-b]pyridine (PhIP) in metabolically competent V79 cells. Mutat Res 521(1-2): 57-72.

136.Kusamran WR, Tepsuwan A, Kupradinun P. 1998. Antimutagenic and anticarcinogenic potentials of some Thai vegetables. Mutat Res 402(12): 247-258. doi: 10.1016/S0027-5107(97)00304-7

137.Lai CN, Butler MA, Matney TS. 1980. Antimutagenic activities of common vegetables and their chlorophyll content. Mutat Res 77(3): 245-250. doi: 10.1016/0165-1218(80)90057-9

138.Ferruzzi MG, Böhm V, Courtney PD, Schwartz SJ. 2002. Antioxidant and antimutagenic activity of dietary chlorophyll derivatives determined by radical scavenging and bacterial reverse mutagenesis assays.J Food Sci 67(7): 2589-2595. doi: 10.1111/j.1365-2621.2002.tb08782.x

139.Edenharder R, Keller G, Platt KL, Unger KK. 2001. Isolation and characterization of structurally novel antimutagenic flavonoids from spinach (Spinaciaoleracea). J Agric Food Chem 49(6): 2767-2773. doi: $10.1021 / \mathrm{jf} 0013712$

140.de Mejía EG, Castaño-Tostado E, Loarca-Piña G.1999. Antimutagenic effects of natural phenolic compounds in beans. Mutat Res 441(1): 1-9. doi: 10.1016/S1383-5718(99)00040-6

141.Cardador-Martínez A, Castaño-Tostado E, Loarca-Piña G. 2002. Antimutagenic activity of natural phenolic compounds present in the common bean (Phaseolus vulgaris) against aflatoxin B1. Food Addit Contam 19(1): 62-69. doi: 10.1080/02652030110062110

142.Pedreschi R, Cisneros-Zevallos L. 2006. Antimutagenic and antioxidant properties of phenolic fractions from Andean purple corn (Zea mays L.).J Agric Food Chem 54(13): 4557-4567. doi: 10.1021/jf0531050

143. Yoshikawa K, Inagaki K, Terashita T, Shishiyama J, Kuo S, et al. 1996. Antimutagenic activity of extracts from Japanese eggplant. Mutat Res 371(1-2): 65-71.doi: 10.1016/S0165-1218(96)90095-6

144.Isidori M, Caterino E, Criscuolo E, Fatigati V, Liguori G, et al. 2009. Antimutagenic and antigenotoxic effects of vegetable matrices on the activity of pesticides. Food Addit Contam Part A Chem Anal Control Expo Risk Assess 26(7): 1049-1062. doi: 10.1080/02652030902896194

145.Gill CI, Haldar S, Porter S, Matthews S, Sullivan S, et al. 2004. The effect of cruciferous and leguminous sprouts on genotoxicity, in vitro and in vivo.Cancer Epidemiol Biomarkers Prev 13(7): 1199-1205.

146.Bunkova R, Marova I, Pokorna Z, Lojek A. 2005. Analysis of plant extracts antimutagenicity using the Ames test and the cytogenetic analysis of peripheral blood lymphocytes. Food Sci Technol Int 11(2): 107-112. doi: 10.1177/1082013205052764

147.Jain AK, Shimoi K, Nakamura Y, Kada T, Hara Y, et al. 1989. Crude tea extracts decrease the mutagenic activity of $\mathrm{N}$-methyl-N'-nitro- $\mathrm{N}$ nitrosoguanidine in vitro and in intragastric tract of rats. Mutat Res 210(1): 1-8. doi: 10.1016/0027-5107(89)90037-7

148.Apostolides Z, Balentine DA, Harbowy ME, Weisburger JH. 1996. Inhibition of 2-amino-1-methyl-6-phenylimidazo[4,5-b]pyridine (PhIP) mutagenicity by black and green tea extracts and polyphenols Mutat Res 359(3): 159-163. doi: 10.1016/S0165-1161(96)90262-9

149.Ito Y, Ohnishi S, Fujie K. 1989. Chromosome aberrations induced by aflatoxin B1 in rat bone marrow cells in vivo and their suppression by green tea. Mutat Res 222(3): 253-261. doi: 10.1016/01651218(89)90141-9

150.Kuroda Y, Hara Y. 1999. Antimutagenic and anticarcinogenic activity of tea polyphenols. Mutat Res 436(1): 69-97. doi: 10.1016/S13835742(98)00019-2

151.Yen GC, Chen HY. 1996. Relationship between antimutagenic activity and major components of various teas. Mutagenesis 11(1): 37-41. doi: 10.1093/mutage/11.1.37
152.Krul C, Luiten-Schuite A, Tenfelde A, van Ommen B, Verhagen H, et al. 2001. Antimutagenic activity of green tea and black tea extracts studied in a dynamic in vitro gastrointestinal model. Mutat Res 474(12): 71-85. doi: 10.1016/S0027-5107(00)00158-5

153.Song BS, Park JG, Park JN, Han IJ, Kim JH, et al. 2009. Korean space food development: Ready-to-eat kimchi, a traditional Korean fermented vegetable, sterilized with highdose gamma irradiation. Adv Space Res 44(2): 162-169. doi: 10.1016/j.asr.2009.03.032

154.Ferguson LR, Denny WA. 2007. Genotoxicity of non-covalent interactions: DNA intercalators. Mutat Res 623(1-2): 14-23. doi: 10.1016/j.mrfmmm.2007.03.014

155.Koch WH, Henrikson EN, Kupchella E, Cebula TA. 1994. Salmonella typhimurium strain TA100 differentiates several classes of carcinogens and mutagens by base substitution specificity. Carcinogenesis 15(1): 7988. doi: $10.1093 /$ carcin/15.1.79

156. Singal PK, Li T, Kumar D, Danelisen I, Iliskovic N. 2000. Adriamycininduced heart failure: mechanism and modulation. Mol Cell Biochem 207(1-2): 77-86. doi: 10.1023/A:1007094214460

157.Guha B, Khuda-Bukhsh AR. 2003. Ameliorating effect of betacarotene on ethylmethanesulphonate-induced genotoxicity in the fish Oreochromismossambicus. Mutat Res 542(1-2): 1-13. doi: 10.1016/j. mrgentox.2003.07.012

158.Achary VMM, Panda BB. 2010. Aluminium-induced DNA damage and adaptive response to genotoxic stress in plant cells are mediated through reactive oxygen intermediates. Mutagenesis 25(2): 201-209. doi: 10.1093/mutage/gep063

159.Beranek DT. 1990. Distribution of methyl and ethyl adducts following alkylation with monofunctional alkylating agents. Mutat Res 231(1): 11-30. doi: 10.1016/0027-5107(90)90173-2

160.Kumaresan KR, Springhorn SS, Lacks SA. 1995. Lethal and mutagenic actions of N-methyl-N'-nitro-N-nitrosoguanidine potentiated by oxidized glutathione, a seemingly harmless substance in the cellular environment. J Bacteriol 177(13): 3641-3646.

161.Bacolod MD, Basu AK. 2001. Mutagenicity of a single 1-nitropyreneDNA adduct N-(deoxyguanosin-8-yl)-1-aminopyrene in Escherichia coli located in a GGC sequence. Mutagenesis 16(6): 461-465. doi: 10.1093/mutage/16.6.461

162.Fronza G, Campomenosi P, Iannone R, Abbondandolo A. 1992. The 4-nitroquinoline 1-oxide mutational spectrum in single stranded DNA is characterized by guanine to pyrimidine transversions. Nucleic Acids Res 20(6): 1283-1287. doi: 10.1093/nar/20.6.1283

163.Gill JP, Romano LJ. 2005. Mechanism for N-acetyl-2-aminofluoreneinduced frameshift mutagenesis by Escherichia coli DNA polymerase I (Klenow fragment). Biochemistry 44(46): 15387-15395. doi: 10.1021/ bi051437s

164.So M, Hvastkovs EG, Bajrami B, Schenkman JB, Rusling JF. 2008. Electrochemical genotoxicity screening for arylamines bioactivated by N-acetyltransferase. Anal Chem 80: 1192-1200. doi: 10.1021/ac701781y

165.Sugamori KS, Brenneman D, Grant DM. 2006. In vivo and in vitro metabolism of arylamineprocarcinogens in acetyltransferasedeficient mice. Drug Metab Dispos 34(10): 1697-1702. doi: 10.1124/ dmd.106.010819

166.DeBaun JR, Smith JY, Miller EC, Miller JA. 1970. Reactivity in vivo of the carcinogen N-hydroxy-2-acetylaminofluorene: increase by sulfate ion. Science 167(3915): 184-186. doi: 10.1126/science.167.3915.184

167.Alpsoy L, Yildirim A, Agar G. 2009. The antioxidant effects of vitamin $\mathrm{A}, \mathrm{C}$, and $\mathrm{E}$ on aflatoxin $\mathrm{B} 1$-induced oxidative stress in human lymphocytes. Toxicol Ind Health 25(2): 121-127. doi: $10.1177 / 0748233709103413$

168.Smith WA, Gupta RC. 1996. Use of a microsome-mediated test system to assess efficacy and mechanisms of cancer chemopreventive agents. Carcinogenesis 17(6): 1285-1290. doi: 10.1093/carcin/17.6.1285 